\title{
Autocrine Hepatocyte Growth Factor Provides a Local Mechanism for Promoting Axonal Growth
}

\author{
Xiu-Ming Yang, ${ }^{1}$ Jean G. Toma, ${ }^{1}$ Shernaz X. Bamji, ${ }^{1}$ Daniel J. Belliveau, ${ }^{1}$ Judi Kohn, ${ }^{1}$ Morag Park, ${ }^{2}$ and \\ Freda D. Miller ${ }^{1}$ \\ ${ }^{1}$ Center for Neuronal Survival, Montreal Neurological Institute, McGill University, Montreal, Quebec, Canada, H3A 2B4, \\ and ${ }^{2}$ Molecular Oncology Group, Royal Victoria Hospital, Montreal, Quebec, Canada, H2W 1S4
}

In this report, we describe a novel local mechanism necessary for optimal axonal growth that involves hepatocyte growth factor (HGF). Sympathetic neurons of the superior cervical ganglion coexpress bioactive HGF and its receptor, the Met tyrosine kinase, both in vivo and in vitro. Exogenous HGF selectively promotes the growth but not survival of cultured sympathetic neurons; the magnitude of this growth effect is similar to that observed with exogenous NGF. Conversely, HGF antibodies that inhibit endogenous HGF decrease sympathetic neuron growth but have no effect on survival. This autocrine
HGF is required locally by sympathetic axons for optimal growth, as demonstrated using compartmented cultures. Thus, autocrine HGF provides a local, intrinsic mechanism for promoting neuronal growth without affecting survival, a role that may be essential during developmental axogenesis or after neuronal injury.

Key words: Met receptor; hepatocyte growth factor/scatter factor; sympathetic neurons; neuronal survival; autocrine growth factors; axonal growth
During development, newborn neurons start to differentiate morphologically, concomitant with terminal mitosis. The newly determined axon extends and finds its way to an appropriate target and undergoes terminal sprouting to innervate that target. Target innervation, however, does not signal the end of axonal growth. In the PNS, axons grow significantly as the animal grows in size, and the extent and nature of target innervation itself are modulated throughout the animal's life (for review, see Purves et al., 1988). Moreover, under certain conditions, axonal growth and regeneration occur after axonal injury (Ramon y Cajal, 1928; Richardson et al., 1980).

Extensive evidence supports the notion that once a neuron reaches its target cells, the density of target innervation is determined at least partially by growth factors produced by the target cells themselves (Campenot, 1982a,b; Edwards et al., 1989; Causing et al., 1997). Similarly, the terminal sprouting, but not axonal regeneration, of adult neurons is apparently mediated by targetderived growth factors (Diamond et al., 1992; Gloster and Diamond, 1992; Miller et al., 1994). However, the nature and source of growth factors that promote developmental axogenesis before target contact and during regeneration of mature axons remain

\footnotetext{
Received June 8, 1998; revised July 23, 1998; accepted Aug. 4, 1998.

This research was supported by grants to F.D.M. from the Canadian Medical Research Council and Canadian NeuroSciences Network. X.-M.Y. and D.J.B. were recipients of fellowships from the Canadian Neurosciences Network and Medical Research Council:Genentech, respectively, and J.K. was supported by a Fonds pour la Formation de Chercheurs et l'Aide à la Recherche studentship. M.P. is a senior scholar of the National Cancer Institute of Canada, and F.D.M. is a Killam Scholar. We thank David Kaplan and Tim Kennedy for critical comments on this manuscript, and Audrey Speelman and Rahul Varma for excellent technical assistance.

Correspondence should be addressed to Dr. F. D. Miller, Center for Neuronal Survival, Montreal Neurological Institute, 3801 rue University, Montreal, Quebec, Canada H3A 2B4.

Dr. Yang's present address: Signal Pharmaceuticals Inc., San Diego, CA 92121.

Dr. Belliveau's present address: Department of Anatomy and Cell Biology, University of Western Ontario, Medical Sciences Building, London, Ontario, Canada M6A 5C1.

Copyright (C) 1998 Society for Neuroscience $\quad 0270-6474 / 98 / 188369-13 \$ 05.00 / 0$
}

ill-defined. In this regard, we have examined the possibility that autocrine growth factors might play a key role, acting as intrinsic "motors" for axonal growth.

Autocrine growth factors have previously been demonstrated to be important for neuronal survival (Acheson et al., 1995; Davies, 1996; Lindholm et al., 1996). Although it has not yet been demonstrated that autocrine trophic factors can specifically modulate neuronal growth, one multifunctional cytokine, hepatocyte growth factor (HGF), is known to function in an autocrine manner to promote motility and transformation of epithelial cells (Rong et al., 1993; Tsao et al., 1993). HGF, which is widely expressed in the embryonic and adult nervous system (Jung et al., 1994), mediates biological activity by binding to its receptor, the Met tyrosine kinase (Bottaro et al., 1991; Naldini et al., 1991). In the nervous system, HGF is a survival factor for motor (Wong et al., 1997; Yamamoto et al., 1997) and sensory neurons (Maina et al., 1997) and is important in vivo for appropriate growth of a subset of embryonic motor neurons (Ebens et al., 1997) and for survival and growth of a subset of dorsal root ganglion neurons (Maina et al., 1997). However, a more widespread analysis of the role of HGF in the nervous system has been hampered by the observation that genetic ablation of either the HGF (Schmidt et al., 1995; Uehara et al., 1995) or Met receptor genes (Bladt et al., 1995 ) results in embryonic lethality by embryonic day 14 . We have therefore turned to an experimentally amenable model system, postmitotic sympathetic neurons, to test the hypothesis that HGF may provide, by analogy to its role in non-neuronal cells, an intrinsic neuronal mechanism for promoting axonal growth. Our studies indicate that sympathetic neurons coexpress HGF and the Met receptor and this autocrine HGF provides an intrinsic local motor for promoting axonal growth without affecting neuronal survival.

\section{MATERIALS AND METHODS}

Mass cultures of sympathetic neurons. Mass cultures of pure sympathetic neurons from the superior cervical ganglion (SCG) of postnatal day 1 rats 
(Sprague Dawley; Charles River Breeding Laboratories, Quebec, Canada) were prepared and cultured either in L15 media as described previously (Ma et al., 1992; Belliveau et al., 1997) or in UltraCulture (BioWhittaker, Walkersville, MD), a defined medium containing $2 \mathrm{~mm}$ glutamine and $1 \%$ penicillin/streptomycin. No differences were observed in experimental results obtained in the two types of media. Neurons were plated on rat tail collagen-coated tissue culture dishes: 6-well plates (Falcon Labware, Becton Dickinson, Lincoln Park, NJ) for biochemistry and 48-well plates for survival assays. Low-density SCG cultures for neurite extension assays were plated on 24-well dishes coated with rat tail collagen.

For survival assays, NGF-dependent neurons were selected by culturing sympathetic neurons for $5 \mathrm{~d}$ in the presence of $50 \mathrm{ng} / \mathrm{ml} \mathrm{NGF}$, as we have described previously (Ma et al., 1992; Belliveau et al., 1997). Neurons were washed three times for $1 \mathrm{hr}$ each in neurotrophin-free media and were then fed with media containing various concentrations of NGF plus HGF, NGF plus anti-HGF, or HGF alone. Analysis of survival was performed $48 \mathrm{hr}$ later by using nonradioactive cell proliferation (MTT) assays (CellTitre 96, Promega, Madison, WI) (Belliveau et al., 1997). Fifty microliters of the MTT reagent were added to $500 \mu \mathrm{l}$ of media in each well and left for $2 \mathrm{hr}$ at $37^{\circ} \mathrm{C}$. After aspiration of the MTT-containing media, $100 \mu \mathrm{l}$ of a $0.065 \mathrm{~N} \mathrm{HCl}$ /isopropanol mixture was added to each well to lyse the cells. Colorimetric analysis was performed using an ELISA reader. Each condition was repeated in triplicate. Zero nanograms/milliliter NGF was considered $0 \%$ survival, and $10 \mathrm{ng} / \mathrm{ml} \mathrm{NGF}$ was considered $100 \%$ survival. All other conditions were related to these values.

For neurite extension assays, neurons were cultured in $10 \mathrm{ng} / \mathrm{ml} \mathrm{NGF}$ for 1 or $4 \mathrm{~d}$. Neurons were then switched into media containing $10 \mathrm{ng} / \mathrm{ml} \mathrm{NGF}$ plus HGF, or $10 \mathrm{ng} / \mathrm{ml} \mathrm{NGF}$ plus anti-HGF. After 2 additional d in culture, neurons were photographed, and the number of neurite intersections was determined as described previously (Belliveau et al., 1997). Briefly, regions in sister cultures containing a similar number of neuronal cell bodies were sampled and photographed, all interceptions and bifurcations of neurites within these windows were counted, and the number of intersections was normalized to the number of cell bodies. At least four windows were analyzed for each sample. Results are expressed as the mean density \pm SEM. Statistical comparison was performed using the Student's $t$ test.

For the $\mathrm{KCl}$ experiments, mass cultures of neonatal sympathetic neurons were cultured as described above at a density of approximately one ganglion per well of a four-well plate. Four days after plating, cultures were washed four times, $1 \mathrm{hr}$ each, with serum- and NGF-free medium. Cultures were then switched to medium containing $50 \mathrm{~mm} \mathrm{KCl}$ with or without added growth factors. Two days after the switch, three independent culture wells were photographed (five photographs per well), and the neurite process density was determined as described above.

Two sources of HGF were used for these experiments: HGF purified from the conditioned medium of COS cells transfected with human HGF cDNA by HPLC (purified hHGF) (Zhu et al., 1994), and recombinant human HGF (rhHGF) kindly provided by Genentech (San Francisco, CA). For purified hHGF, quantitation of activity was performed using scatter assays (see below) (Stoker et al., 1987); the lowest amount of purified hHGF that caused Madin-Darby canine kidney (MDCK) cells to scatter was considered to be one unit. Two previously characterized, function-blocking HGF antibodies were also used: a sheep anti-rhHGF antiserum provided by Genentech (the kind gift of Dr. Ralph Schmall) (Tsao et al., 1993), or purified goat anti-human HGF IgG purchased from Sigma (St. Louis, MO) (Rubin et al., 1991).

Compartmented cultures of sympathetic neurons. Compartmented cultures of pure sympathetic neurons were established according to previously described procedures (Campenot, 1992; Toma et al., 1997). Briefly, SCGs were removed from postnatal day 1 rats. The ganglia were subjected to a combined trypsin and mechanical dissociation procedure and plated into compartmented dishes. The compartmented dishes were constructed from collagen-coated $35 \mathrm{~mm}$ Falcon tissue culture dishes in which 20 parallel collagen tracks had been formed on the dish by scraping the dried collagen from the dish surface with a pin rake (Tyler Research Instruments, Edmonton, Alberta, Canada). In some experiments, the dishes were coated with poly-D-lysine and laminin, and the tracks were formed in the same manner. The scratched region of the dish was then wetted with culture medium, and a Teflon divider (Tyler Research Instruments) that partitioned the dish into three compartments was sealed to the dish floor with silicone grease. Dissociated sympathetic neurons were plated in the center compartment at a density of $\sim 1.5$ ganglia per dish as previously described, and within 1-2 d neurites had entered the left and right compartments. Culture medium was Ultra-
Culture (BioWhittaker) supplemented with $2 \mathrm{~mm}$ L-glutamine, $1 \%$ penicillin/streptomycin (BioWhittaker) and 0.4\% methylcellulose (Sigma). Unless indicated otherwise, $3 \%$ rat serum (Harlan, Indianapolis, IN) was added only to the center compartments that contained the cell bodies and proximal neurites. Non-neuronal cells were eliminated using $10 \mu \mathrm{M}$ cytosine arabinoside (Sigma) in the central compartment during the first $4-5 \mathrm{~d}$ in culture. All three compartments were supplied with $2.5 \mathrm{~S}$ NGF (Cedarlane Laboratories, Hornby, Ontario, Canada) as described below. To examine the effects of HGF or function-blocking HGF antibodies on axon extension in the side compartments, neurons were plated in the central compartment in the above medium supplemented with $10 \mathrm{ng} / \mathrm{ml}$ NGF. On day zero of culturing, the right compartment received either 1 or $3 \mathrm{ng} / \mathrm{ml}$ NGF plus $30 \mathrm{ng} / \mathrm{ml}$ HGF (Genentech), or $10 \mathrm{ng} / \mathrm{ml} \mathrm{NGF}$ plus $5 \mu \mathrm{l} / \mathrm{ml}$ anti-rhHGF antiserum (Genentech). The left compartment of each culture received either 1,3 , or $10 \mathrm{ng} / \mathrm{ml} \mathrm{NGF}$ with or without the addition of $5 \mu \mathrm{l} / \mathrm{ml}$ nonimmune sheep serum (Sigma) and served as a control. Alternatively, anti-rhHGF was added to the center compartment. Within 1-2 d neurites crossed the silicone grease barriers and entered the side compartments in all cultures. Culture medium was routinely changed every 3-4 d. Neurite extension along each track in the right and left compartments of each culture was measured by an ocular micrometer using an inverted phase-contrast microscope (Axiovert 100, Carl Zeiss). Neurite extension was measured at time points ranging from 2 to $7 \mathrm{~d}$. Results are expressed as mean neurite extension $\pm \mathrm{SEM}$, and statistical analysis was performed using the Student's $t$ test.

For the $\mathrm{KCl}$ experiments, compartmented cultures of neonatal sympathetic neurons were established as above, and after $4 \mathrm{~d}$ cultures were washed four times for $1 \mathrm{hr}$ each, with serum- and neurotrophin-free medium. After these washes, cell bodies and proximal neurites were switched to media containing $50 \mathrm{~mm} \mathrm{KCl}$, and the side compartments were switched to the same medium with or without $30 \mathrm{ng} / \mathrm{ml} \mathrm{HGF}$.

Scatter assays. For detection of bioactive HGF, neurons were cultured for $4 \mathrm{~d}$ in $10 \mathrm{ng} / \mathrm{ml} \mathrm{NGF}$, followed by three washes with neurotrophin-free media for $1 \mathrm{hr}$ each. Neurons were then switched to the same media plus 10 $\mathrm{ng} / \mathrm{ml} \mathrm{NGF}$, and conditioned media was collected 8 or $24 \mathrm{hr}$ later. For the scatter assay, MDCK cells were cultured in DMEM medium and plated at a density of $2 \times 10^{4}$ cells in a 24-well dish and left to settle overnight. MDCK cells were then switched to DMEM medium containing a 1:100 dilution of the sympathetic neuron conditioned-media, or unconditioned medium (with or without $10 \mathrm{ng} / \mathrm{ml}$ of NGF), and left for 8 or $24 \mathrm{hr}$. Scatter activity was analyzed as described previously (Stoker et al., 1987).

In situ hybridization. SCGs were dissected from adult CD1 mice, fixed in $4 \%$ paraformaldehyde in PBS for $30 \mathrm{~min}$, and cryoprotected in graded sucroses $(12,16$, and $18 \%)$. Cryostat sections $(10 \mu \mathrm{m})$ were cut, mounted on Superfrost slides (Fisher Scientific, Houston, TX), briefly air-dried, fixed in $4 \%$ paraformaldehyde in PBS for $5 \mathrm{~min}$ at room temperature, and washed twice in PBS. For in situ hybridization, slides were treated with proteinase $\mathrm{K}(1 \mu \mathrm{g} / \mathrm{ml})$ in $0.1 \mathrm{M}$ Tris-HCl, pH 7.5, $50 \mathrm{~mm}$ EDTA, and $2 \mathrm{mM} \mathrm{CaCl}_{2}$ at $37^{\circ} \mathrm{C}$ for $10 \mathrm{~min}$, followed by incubation in $0.1 \mathrm{M}$ triethanolamine containing $0.25 \%$ acetic anhydride for $10 \mathrm{~min}$. Slides were washed in $3 \times$ PBS for 5 min, followed by three washes with $2 \times$ SSC for $5 \mathrm{~min}$ each, and then prehybridized in a buffer containing $50 \%$ deionized formamide, $5 \times \mathrm{SSC}, 5 \times$ Denhardt's solution, $250 \mathrm{mg} / \mathrm{ml}$ tRNA, and $200 \mathrm{mg} / \mathrm{ml}$ salmon sperm DNA at room temperature for at least $1 \mathrm{hr}$. Sections were hybridized in the same solution plus $5 \mathrm{ng} / \mathrm{ml}$ digoxigenin-labeled probes at $45^{\circ} \mathrm{C}$ overnight. Slides were then washed once with $2 \times$ SSC for $20 \mathrm{~min}$, treated with $25 \mu \mathrm{g} / \mathrm{ml}$ RNase in $0.1 \mathrm{M}$ Tris plus $150 \mathrm{~mm} \mathrm{NaCl}$ for $30 \mathrm{~min}$ at $37^{\circ} \mathrm{C}$ twice, followed by washing twice with $0.2 \times \mathrm{SSC}$ and twice with $0.1 \times \mathrm{SSC}$ at $55^{\circ} \mathrm{C}$ for $15 \mathrm{~min}$ each, and then blocked with $2 \%$ normal sheep serum and $0.3 \%$ Triton X-100 in buffer 1 (100 mm Tris-HCl, pH 7.5, $150 \mathrm{~mm} \mathrm{NaCl})$ for $1 \mathrm{hr}$. To detect specific hybrids, slides were then incubated with anti-digoxigenin antibody conjugated to alkaline phosphatase (1-1000 dilution in buffer 1) for $30 \mathrm{~min}$, then washed twice (15 min each) with buffer 1 , and rinsed in buffer 3 (100 mm Tris- $\mathrm{HCl}, \mathrm{pH} 9.5,100 \mathrm{~mm} \mathrm{NaCl}$, and $50 \mathrm{~mm} \mathrm{MgCl}_{2}$ ). The hybrids bound to anti-digoxigenin antibody are visualized by the color reaction with $337.5 \mu \mathrm{g} / \mathrm{ml}$ nitroblue tetrazolium salt (NBT), 175 $\mu \mathrm{g} / \mathrm{ml}$ 5-bromo-4-chloro-3-indolyl-phosphate, and $0.24 \mu \mathrm{g} / \mathrm{ml}$ levamisole in buffer 3 , and color was allowed to develop overnight in the dark. The reaction was terminated by incubation with $100 \mathrm{~mm}$ Tris-HCl, $\mathrm{pH} 8.0,1$ mM EDTA for $5 \mathrm{~min}$. Slides were dehydrated, incubated in xylene, mounted with Permount, and stored at $4^{\circ} \mathrm{C}$ in the dark. Slides were viewed and photographed on a light microscope.

The probe used for Met in situ hybridization corresponded to nucleotides 434-886 of the murine cDNA (Yang et al., 1996). HGF antisense 
probes were used as described in Sonnenberg et al. (1993). Nonradioactive antisense and sense riboprobes were synthesized by in vitro transcription using digoxigenin-UTP following the manufacturer's instructions (Boehringer Mannheim, Indianapolis, IN).

Immunocytochemistry. Cryosections of adult SCG were prepared as described for in situ hybridization. Sympathetic neurons were plated on poly-D-lysine plus laminin-coated coverslips, maintained for $4 \mathrm{~d}$ in 10 $\mathrm{ng} / \mathrm{ml}$ of NGF, and then fixed in acetone and methanol $(1: 1 \mathrm{v} / \mathrm{v})$ for $5 \mathrm{~min}$ at room temperature and allowed to air dry. Sections (on slides prepared as above) or sympathetic neurons (on coverslips) were blocked with $4 \%$ goat serum plus $4 \%$ rat serum in PBS supplemented with $0.1 \%$ Tween-20 (PBST) for $1 \mathrm{hr}$, incubated with an anti-Met peptide antibody $(1: 150)$ (Yang and Park, 1993) with or without $10 \mu \mathrm{g}$ of competed peptide at $4^{\circ} \mathrm{C}$ overnight, and then washed three times for $15 \mathrm{~min}$ each with PBST. To visualize the primary antibody, sympathetic neurons on coverslips were incubated with CY3-conjugated goat anti-rabbit IgG antibody (1:2000) (Jackson ImmunoResearch, West Grove, PA), washed three times for 15 min each with PBST, and mounted using Sigma mounting medium. Tissue sections were incubated with biotinylated anti-rabbit IgG, and the ABC visualization kit (Vector Laboratories, Burlingame, CA) was used according to the manufacturer's instructions.

$R N A$ extraction and reverse transcriptase PCR amplification. Tissues (including SCGs) were dissected from adult CD1 mice, and total RNA was prepared following the protocol of Chomczynski and Sacchi (1987). cDNA was synthesized from $5 \mu \mathrm{g}$ of total RNA using the cDNA synthesis kit from Life Technologies BRL (Gaithersburg, MD) following the manufacturer's instructions. To amplify an HGF-specific product, two oligonucleotide primers P1 (5'-484 CCATGAATTTGACCTCTATG 503-3') and P2 (5'-760 ACTGAGGAA-TGTCACAGACT 741-3') were selected. Two specific oligonucleotide primers were also used to detect Met specific product: P3 (5'-272 AGATGAACGTGAACATGAAG 291-3') and P4 (5'-566 CTAATGAGTTGATCATCATAG 546-3'). The $\mathrm{PCR}$ reaction contained $10 \mathrm{~mm}$ Tris- $\mathrm{HCl}, \mathrm{pH} 8.3,50 \mathrm{~mm} \mathrm{KCl,} 1.5 \mathrm{~mm}$ $\mathrm{MgCl}_{2}, 0.01 \%$ gelatin, $200 \mathrm{~mm} \mathrm{dNTP}, 10 \mathrm{pM} 5^{\prime}$ and $3^{\prime} \mathrm{HGF}$ oligonucleotide primers, $2 \mu \mathrm{l}$ of cDNA template, and $1 \mathrm{U}$ of Taq polymerase (BRL, Bethesda, MD). Amplification was performed for 45 cycles: $94^{\circ} \mathrm{C}(1 \mathrm{~min})$, $48^{\circ} \mathrm{C}(2 \mathrm{~min})$, and $72^{\circ} \mathrm{C}(2 \mathrm{~min})$ in a Perkin-Elmer Cetus DNA thermal cycler. The PCR products were separated on a $1.5 \%$ agarose gel and transferred to a Hybond N membrane (Amersham, Arlington Heights, IL). An internal HGF (P5, 5'-656 ACCTACAGGAAAACTACTG 675$3^{\prime}$ ) or Met oligonucleotide (P6, 5'-487 TGGCTTTGCTGCTGCAGTC 469-3') (100 ng) was end-labeled using T4 polynucleotide kinase. The membrane was prehybridized in $6 \times \mathrm{SSC}, 1 \% \mathrm{SDS}, 5 \times$ Denhardt's solution, and $200 \mu \mathrm{g} / \mathrm{ml}$ salmon sperm DNA at $42^{\circ} \mathrm{C}$ for $1 \mathrm{hr}$ and then hybridized in the same solution plus $50 \%$ formamide and $1 \times 10^{6}$ $\mathrm{cpm} / \mathrm{ml}$ of labeled oligonucleotide probe at $42^{\circ} \mathrm{C}$ overnight. The membrane was washed with $2 \times \mathrm{SSC}$ and $0.1 \% \mathrm{SDS}$ for $15 \mathrm{~min}$ and then exposed to x-ray film.

Immunoprecipitations and Western blot analysis. Primary neonatal sympathetic neurons cultured for $4 \mathrm{~d}$, postnatal day 1 SCGs, or compartmented cultures of sympathetic neurons were lysed in cold Tris-buffered saline (TBS) containing $137 \mathrm{~mm} \mathrm{NaCl}, 20 \mathrm{~mm}$ Tris, $\mathrm{pH} 8.0,1 \%(\mathrm{v} / \mathrm{v})$ NP-40, $10 \%$ (v/v) glycerol, $1 \mathrm{~mm}$ phenylmethyl sulfonyl fluoride (PMSF), $10 \mu \mathrm{g} / \mathrm{ml}$ aprotinin, $0.2 \mathrm{mg} / \mathrm{ml}$ leupeptin, $5 \mathrm{~mm}$ phenanthroline, and 1.5 mM sodium vanadate. The lysates were normalized for protein concentration using a BCA Protein Assay Reagent (Pierce, Rockford, I11). For analysis of Met, $1.25 \mathrm{mg}$ of protein was immunoprecipitated with $10 \mu \mathrm{l}$ of anti-Met peptide antibody for $3 \mathrm{hr}$ at $4^{\circ} \mathrm{C}$ (Yang and Park, 1993) and then incubated with Protein A-Sepharose (Pharmacia, Dorval, Québec, Canada) for $1.5 \mathrm{hr}$ at $4^{\circ} \mathrm{C}$ followed by centrif ugation. Alternatively, $1.25 \mathrm{mg}$ of protein was precipitated with wheat germ lectin-agarose (WGA) (Pharamacia) for $3 \mathrm{hr}$. In both cases, the precipitate was washed three times with cold lysis buffer, and proteins were separated on an $8 \%$ SDS-PAGE gel and then transferred to $0.2 \mu \mathrm{m}$ nitrocellulose for $1.0 \mathrm{hr}$ at 0.5 amps. Transferred membranes were then washed $2 \times 10 \mathrm{~min}$ in TBS, blocked in 2\% BSA (Sigma) in TBS for $2.5 \mathrm{hr}$, washed $2 \times 10 \mathrm{~min}$ in TBS, and incubated overnight at $4^{\circ} \mathrm{C}$ with the anti-Met-peptide antibody (1:150). Secondary antibodies were incubated for $1.5 \mathrm{hr}$ at room temperature and were used at dilution of 1:2000 for Protein A-HRP (Sigma). Detection was performed using enhanced chemiluminescence (Amersham) and XAR x-ray film (Kodak, Rochester, NY).

Analysis of tubulin in the neurites of sympathetic neurons in compartmented cultures was performed by Western blot analysis. Compartmented cultures were established on a poly-D-lysine and laminin substratum with 10 $\mathrm{ng} / \mathrm{ml} \mathrm{NGF}$ in all compartments and $5 \mu \mathrm{l} / \mathrm{ml}$ anti-HGF (Genentech) in one side compartment. Six days after establishment of the cultures, the neurites from each side compartment were lysed in cold Tris-buffered saline lysis buffer as described above except that SDS was added to a final concentration of $0.1 \%$. For analysis of tubulin levels, $20 \mu \mathrm{g}$ of total protein from each treatment group was separated by SDS-PAGE on a $7.5 \%$ gel and transferred to $0.2 \mu \mathrm{m}$ nitrocellulose membrane. The transferred membranes were then washed in TBS and blocked in $2 \%$ BSA as described above. The membranes were incubated at $4^{\circ} \mathrm{C}$ with an $\alpha$-tubulin monoclonal antibody (Cedarlane Laboratories, Hornby, Ontario, Canada) at a concentration of $0.05 \mu \mathrm{g} / \mathrm{ml}$. Detection was performed using enhanced chemiluminescence (Amersham) and XAR x-ray film (Kodak).

$c$-fos stimulation. Acutely dissociated sympathetic neurons from postnatal day 1 rat SCG were plated on poly-D-lysine- and laminin-coated coverslips in $\mathrm{L} 15-\mathrm{CO}_{2}$ medium without NGF for $3 \mathrm{hr}$ (Wyatt and Davies, 1995). Neurons were then cultured with media containing various amounts of HGF or NGF for $3 \mathrm{hr}$. Cells were fixed in acetone and methanol $(1: 1, \mathrm{v} / \mathrm{v})$, blocked with $2 \%$ goat serum in PBST, and then incubated with anti-fos antibody (1:50) (Oncogene Science) overnight at $4^{\circ} \mathrm{C}$. After $3 \times 15 \mathrm{~min}$ washes with PBST, cells were incubated with biotinylated anti-mouse $\operatorname{IgG}$, and the antibody reaction was detected using the ABC kit. For the function-blocking antibody experiments, HGF was preincubated with an excess amount of anti-HGF antibody (Genentech) at $4^{\circ} \mathrm{C}$ for $3 \mathrm{hr}$ and then added to the culture medium for $3 \mathrm{hr}$.

\section{RESULTS}

\section{HGF and its receptor, the Met tyrosine kinase, are coexpressed in sympathetic neurons in vivo and in culture}

To determine whether HGF and its receptor, the Met tyrosine kinase, are expressed in sympathetic neurons, we first examined the mouse SCG by RT-PCR (Fig. 1A,B). Total RNA was isolated from the neonatal and adult SCG and, for comparison, from the adult brain and liver, both of which are known to express HGF and Met mRNAs. RT-PCR analysis revealed that HGF and Met mRNAs were expressed in both the newborn (data not shown) and the adult SCG (Fig. 1A,B). To determine whether HGF and Met were expressed in neurons or in non-neuronal cells, we performed in situ hybridization on serial sections through the adult mouse SCG using digoxigenin-labeled riboprobes. HGF and Met receptor mRNAs (Fig. $2 A, B$ ) were expressed in most, if not all, sympathetic neurons of the SCG. Moreover, both HGF and Met mRNAs were clearly localized to the same neurons (Fig. $2 A, B)$. The specificity of this analysis was determined by hybridizing adjacent sections with sense Met or HGF riboprobes, neither of which produced any detectable signal (data not shown).

To confirm that Met protein was also expressed in the mouse SCG, lysates of the postnatal day 1 (Fig. 1C) or adult (data not shown) SCG were precipitated either with a previously characterized antibody to Met (Yang and Park, 1993) or with wheat germ agglutinin (WGA), which binds glycosylated proteins. These precipitates were then separated on polyacrylamide gels (SDS-PAGE) and transferred to nitrocellulose, and the filters were incubated with the same Met antibody. This analysis revealed a Met-immunoreactive band of $145 \mathrm{kDa}$ in both the SCG and the adult liver (Fig. 1C). This immunoreactive band was abolished when the Met antibody was first incubated with the Met immunizing peptide (Fig. 1C), demonstrating its specificity. Immunocytochemistry confirmed that like Met mRNA, Met protein was localized to sympathetic neurons of the SCG (Fig. 2C): Met-like immunoreactivity was distributed throughout the ganglion, both in fibers coursing through the body of the ganglion and in sympathetic neuron cell bodies (Fig. 2C). No staining was observed when the antibody was preabsorbed with the immunizing Met peptide before immunocytochemistry (data not shown). Thus, mature sympathetic neurons coexpress HGF and its receptor, the Met tyrosine kinase, in vivo. 
A

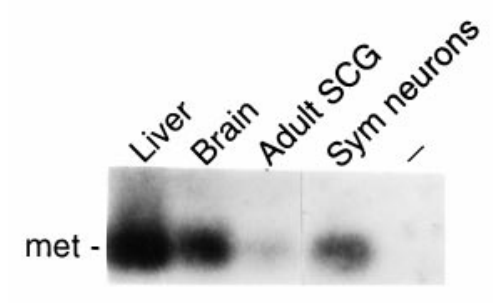

B
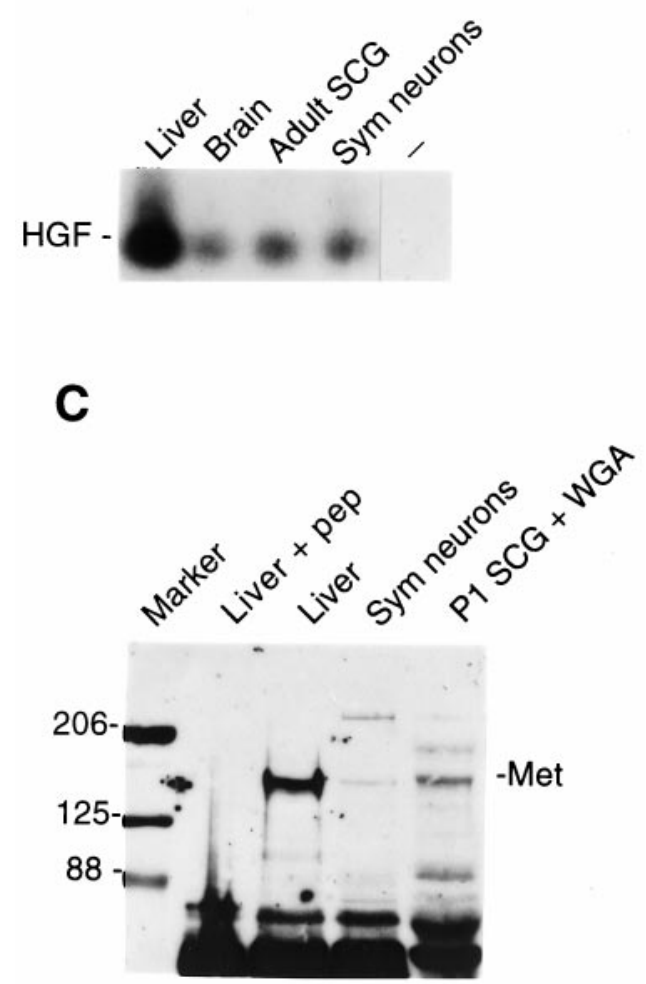

Figure 1. HGF and Met are expressed in sympathetic neurons of the SCG in vitro and in vivo. $A, B$, RT-PCR analysis of $5 \mu \mathrm{g}$ of total RNA with primers specific to Met $(A)$ or HGF $(B)$ mRNAs. The PCR product was visualized by autoradiography after Southern blot analysis of the transferred PCR products with radiolabeled internal oligonucleotides specific to the predicted Met $(A)$ or HGF $(B)$ PCR products. Total RNA for analysis was isolated from adult liver (Liver), brain (Brain), superior cervical ganglia (Adult SCG), and cultured neonatal sympathetic neurons (Sym neurons). The short dash (-) indicates that no cDNA was added to the RT-PCR reaction. $C$, Western blot analysis of lysates from various tissues that were precipitated with either Met antibody (Liver + pep, Liver, Sym neurons) or wheat germ agglutinin ( $P 1 S C G+W G A)$ and then probed with anti-Met. Sym neurons refers to cultured sympathetic neurons, and P1 SCG refers to the intact postnatal day $1 \mathrm{SCG}$. The $145 \mathrm{kDa}$ Met band is indicated, and the size markers are denoted to the left of the blot. Note that the $145 \mathrm{kDa}$ Met-immunoreactive band is abolished by preincubation of the Met antibody with the Met immunizing peptide (Liver + pep $)$.

To determine the role of the coexpressed HGF and Met, we turned to cultures of pure $(>95 \%)$ neonatal rat sympathetic neurons from the SCG. We first used RT-PCR to confirm that cultured sympathetic neurons also expressed HGF and Met re-
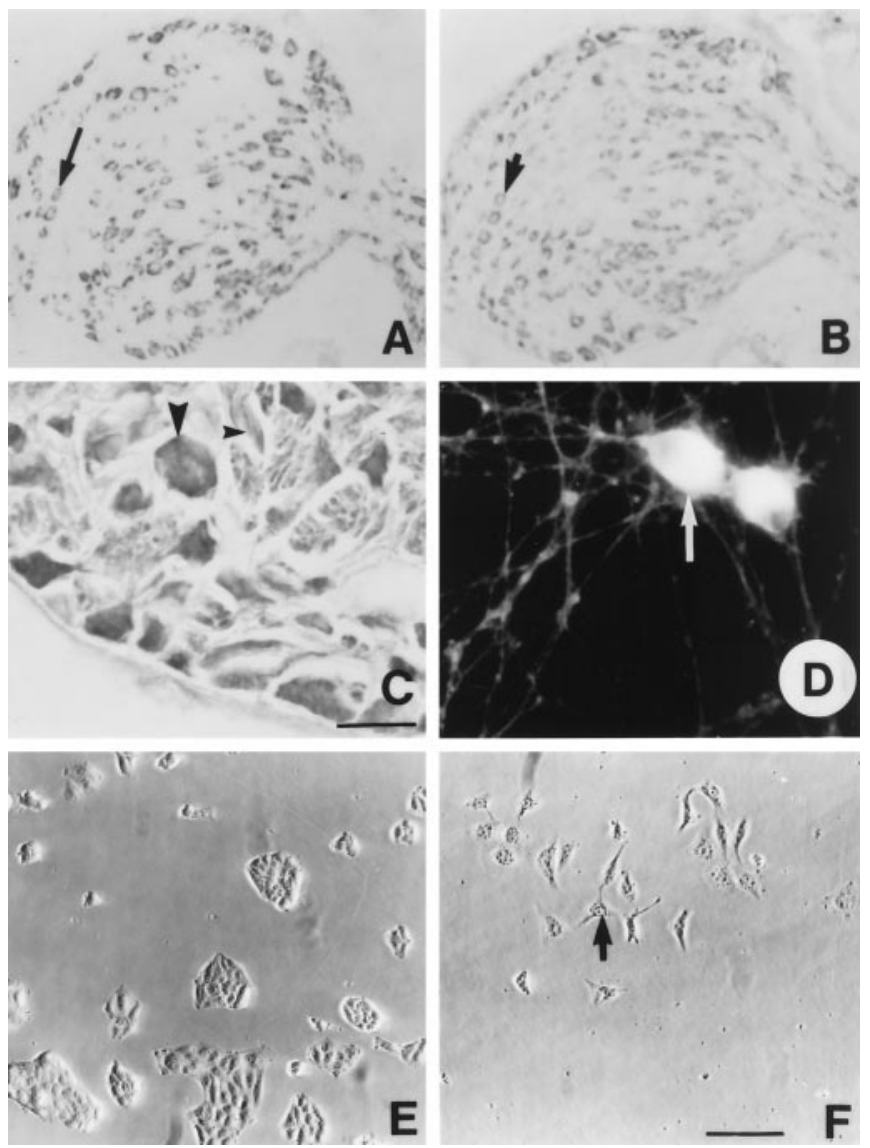

Figure 2. Coexpression of HGF and the Met receptor in postnatal and adult sympathetic neurons. $A, B$, Digoxigenin-based in situ hybridization of serial sections from the adult mouse SCG with antisense riboprobes specific for Met $(A)$ and HGF $(B)$ mRNAs. An example of a sympathetic neuron that is present in both sections and is positive for both HGF and Met mRNAs is denoted by the arrows in $A$ and $B . C$, Immunocytochemistry for Met protein in sections of the adult mouse SCG as visualized using $\mathrm{DAB}$, which causes a dark reaction product. Met-like immunoreactivity is present throughout the SCG both in neuronal cell bodies (large arrowhead) and in processes (small arrowhead). D, Fluorescence photomicrograph from the immunocytochemical analysis of cultured neonatal sympathetic neurons with an antibody specific for the Met receptor. Met-like immunoreactivity is distributed throughout the cell bodies and processes of cultured sympathetic neurons (arrow indicates a cell body). $E, F$, Phase photomicrographs of MDCK cells that were allowed to cluster and then were exposed to $(E)$ unconditioned sympathetic neuron medium or $(F)$ NGF-containing medium conditioned by cultured neonatal sympathetic neurons for $24 \mathrm{hr}$. Note that the medium conditioned by sympathetic neurons causes the MDCK cells to "scatter" (arrow in $F$ ). Scale bars (shown in $C$ for $A-C$ ): $A, B, 75 \mu \mathrm{m} ; C, 36 \mu \mathrm{m}$; (shown in $F$ for $D-F$ ): $D$, $30 \mu \mathrm{m} ; E, F, 157 \mu \mathrm{m}$.

ceptor mRNAs (Fig. 1A,B). We next determined whether neonatal sympathetic neurons expressed the Met receptor protein, as predicted by their synthesis of Met receptor mRNA. Cellular lysates of cultured neonatal sympathetic neurons were immunoprecipitated with anti-Met, and the precipitates were analyzed by Western blot analysis with the same Met antibody. This analysis demonstrated that like the intact SCG (Fig. 1C), cultured sympathetic neurons expressed a Met-immunoreactive band of the same size as that observed in liver (Fig. $1 C$ ). To determine the spatial localization of this Met protein, we also performed immunocytochemistry (Fig. 2D). This analysis demonstrated that virtually all of the cultured neurons expressed Met, and that the Met 
immunoreactivity was localized to both neurites and cell bodies. This immunostaining was abolished when the Met antibody was first preabsorbed with the immunizing Met peptide (data not shown).

Finally, we determined whether bioactive HGF was synthesized and secreted by sympathetic neurons using scatter assays, which take advantage of the fact that HGF causes cultured MDCK cells to become motile and "scatter" (Stoker et al., 1987). Sympathetic neurons were cultured in NGF for $4 \mathrm{~d}$, washed thoroughly, and then switched into new medium containing 10 $\mathrm{ng} / \mathrm{ml}$ NGF. Twenty-four hours later, the sympathetic neuronconditioned media was removed, diluted at 1:100 into DMEM media, and transferred onto MDCK cells, which grow as tight clusters under standard culture conditions (Fig. 2E). Twenty-four hours after MDCK cells were transferred to sympathetic neuronconditioned media, they scattered in a manner similar to that obtained with exogenous HGF (Fig. 2F) (Stoker et al., 1987). In contrast, no scattering was observed when unconditioned media, with or without $10 \mathrm{ng} / \mathrm{ml} \mathrm{NGF}$, was added to MDCK cells. Thus, cultured sympathetic neurons synthesize and secrete bioactive HGF-like scattering activity, most likely HGF itself.

\section{Exogenous HGF stimulates immediate early gene expression but not survival of sympathetic neurons}

The coexpression of HGF and the Met receptor in sympathetic neurons raised the possibility that HGF may function as an autocrine neurotrophic factor for these neurons. As a first step in investigating this possibility, we determined whether HGF was able to stimulate a functional Met receptor-mediated signaling response, as monitored by the immediate early gene c-fos. Previous work has demonstrated that HGF leads to an immediate activation of c-fos expression in epithelial cells and in septal neurons (Fabregat et al., 1992; Jung et al., 1994). To perform these experiments, sympathetic neurons of the postnatal day 1 SCG were acutely dissociated (Wyatt and Davies, 1995), exposed to $10 \mathrm{ng} / \mathrm{ml} \mathrm{NGF}$ or to $10 \mathrm{ng} / \mathrm{ml} \mathrm{rhHGF}$ for $3 \mathrm{hr}$, and analyzed immunocytochemically for c-fos expression (Fig. 3). This analysis demonstrated that HGF was capable of eliciting a robust induction of c-fos in $\sim 80-90 \%$ of the sympathetic neurons in these acutely dissociated cultures (Fig. $3 a, d$ ), a response equivalent to that invoked by $10 \mathrm{ng} / \mathrm{ml} \mathrm{NGF} \mathrm{(Fig.} \mathrm{3a,b).} \mathrm{These} \mathrm{data,} \mathrm{together}$ with the immunocytochemical data, indicate that the vast majority of cultured sympathetic neurons express the Met receptor and can respond biologically to HGF.

We next determined whether Met signaling induced by HGF binding could support the survival of NGF-dependent sympathetic neurons. Neurons were selected for $5 \mathrm{~d}$ in $50 \mathrm{ng} / \mathrm{ml} \mathrm{NGF}$, washed thoroughly with neurotrophin-free medium, and switched to various quantities of NGF or rhHGF, and survival was measured 2 d later using MTT assays (Belliveau et al., 1997). This analysis indicated that concentrations of HGF of up to $100 \mathrm{ng} / \mathrm{ml}$ were unable to support survival of NGF-dependent sympathetic neurons (Fig. 4A). Similarly, when 100 or $200 \mathrm{ng} / \mathrm{ml} \mathrm{rhHGF}$ was added to sympathetic neurons immediately on plating, no neurons survived (data not shown), indicating the absence of an HGF-dependent population of neurons in the SCG.

\section{Exogenous HGF selectively promotes sympathetic neuron growth}

To test the possibility that HGF might be promoting neuronal growth rather than survival, we examined neurite extension in cultures of sympathetic neurons maintained in $10 \mathrm{ng} / \mathrm{ml} \mathrm{NGF}$.

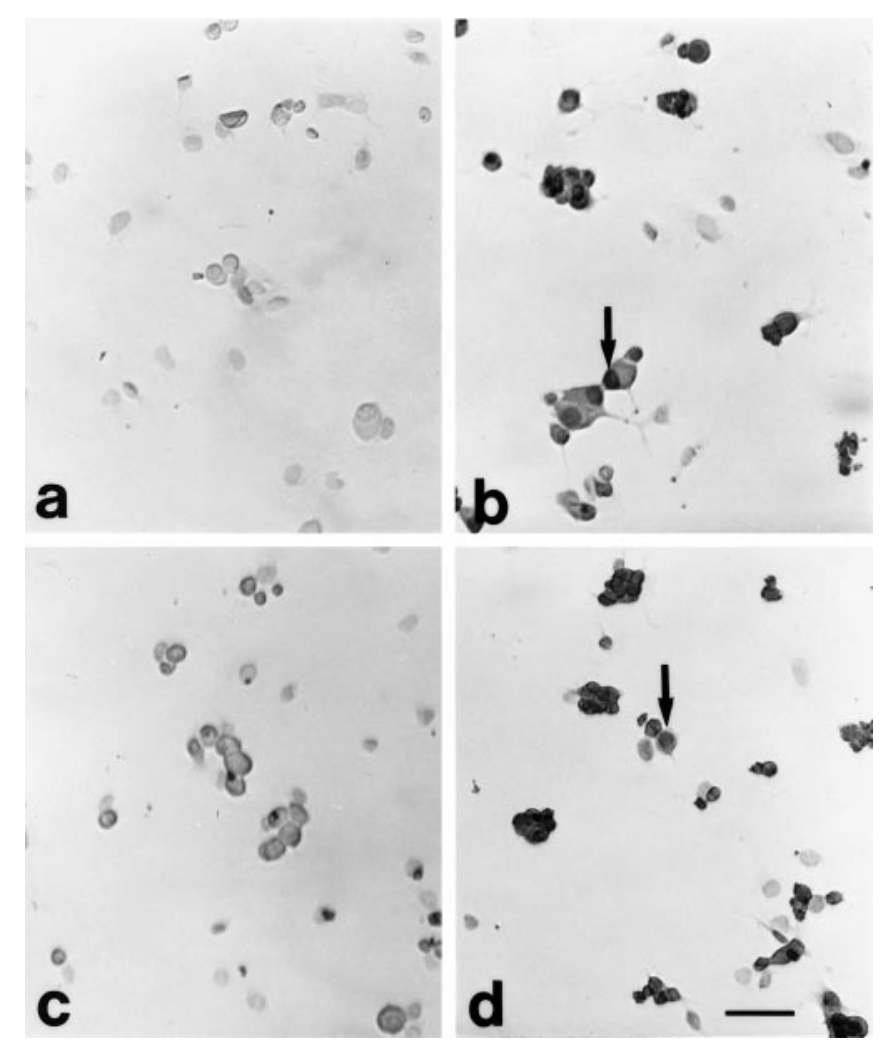

Figure 3. Treatment with exogenous HGF induces c-fos expression in the vast majority of cultured sympathetic neurons. Immunocytochemistry of cultured sympathetic neurons with an antibody specific for the immediate early gene c-fos, as visualized with DAB. Acutely dissociated sympathetic neurons from the P1 SCG were exposed to no added neurotrophin $(a)$, to $10 \mathrm{ng} / \mathrm{ml} \mathrm{NGF}(b)$, or to $10 \mathrm{ng} / \mathrm{ml} \mathrm{rhHGF}(d)$ for $3 \mathrm{hr}$. Note that the c-fos immunoreactivity is much more intense in neurons treated with NGF $(b)$ or HGF $(d)$ and in many cases is localized to the nucleus (arrows). In contrast, when the rhHGF was preabsorbed with an antibody to HGF (Genentech), this induction was greatly diminished (c). Scale bar, $45 \mu \mathrm{m}$.

Specifically, sympathetic neurons were plated at low density for $1 \mathrm{~d}$ (Fig. 4D, Exp 1-3) or $4 \mathrm{~d}$ (Fig. 4D, Exp 4) in the presence of $10 \mathrm{ng} / \mathrm{ml}$ NGF. This concentration of NGF mediates $100 \%$ sympathetic neuron survival, but elicits limited morphological growth and TrkA activation relative to higher concentrations of NGF (Ma et al., 1992; Belliveau et al., 1997). Cultures were then switched to fresh media containing $10 \mathrm{ng} / \mathrm{ml} \mathrm{NGF}$ with or without $30 \mathrm{ng} / \mathrm{ml} \mathrm{rhHGF}$ (Fig. 4D, Exp 1-3) and $10 \mathrm{U} / \mathrm{ml}$ purified hHGF (Fig. 4D, Exp 4), or for comparison, $30 \mathrm{ng} / \mathrm{ml} \mathrm{NGF} \mathrm{(a} \mathrm{total} \mathrm{of} 40$ ng/ml NGF) (Fig. 4D). Two days later, fields were randomly selected, and the process network density was determined. In four separate experiments, the process network density was increased $2.0 \pm 0.10$ in the presence of $10 \mathrm{U} / \mathrm{ml}$ or $30 \mathrm{ng} / \mathrm{ml} \mathrm{HGF}$ versus NGF alone (Figs. 4D, 5a,b). Similarly, $40 \mathrm{ng} / \mathrm{ml}$ NGF increased neurite density $\sim 2.3$-fold relative to $10 \mathrm{ng} / \mathrm{ml} \mathrm{NGF}$ alone (Fig. $4 D$ ), an increase similar to the 2-2.5-fold increase we have documented previously for $30 \mathrm{ng} / \mathrm{ml} \mathrm{NGF}$ relative to $10 \mathrm{ng} / \mathrm{ml} \mathrm{NGF}$ (Belliveau et al., 1997). Thus, when neuronal survival is maintained with NGF, exogenous HGF enhances sympathetic neuron growth to approximately the same degree as the addition of a similar amount of exogenous NGF (Fig. 4D, right panel), the most potent growth factor known for these neurons.

These experiments indicate that exogenous HGF promotes sympathetic neuron growth in the presence of NGF, which itself 


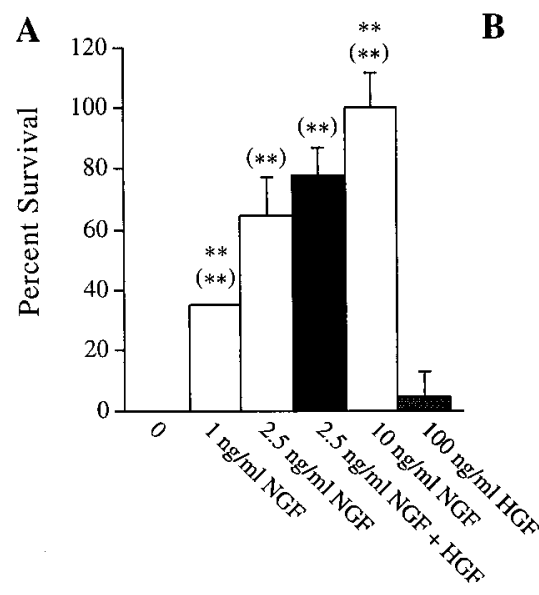

D

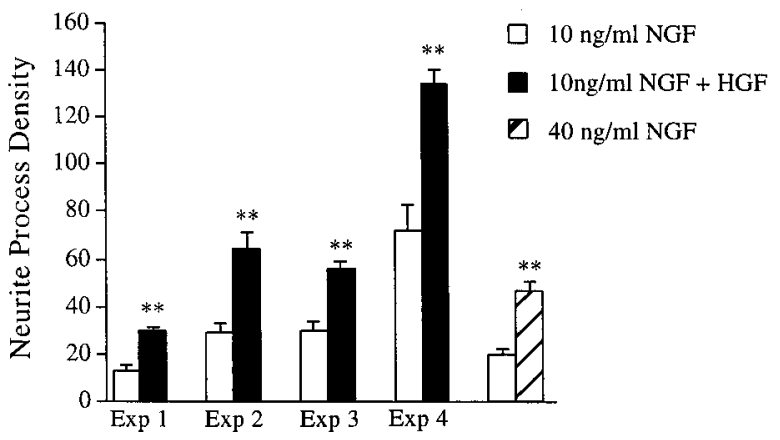

E

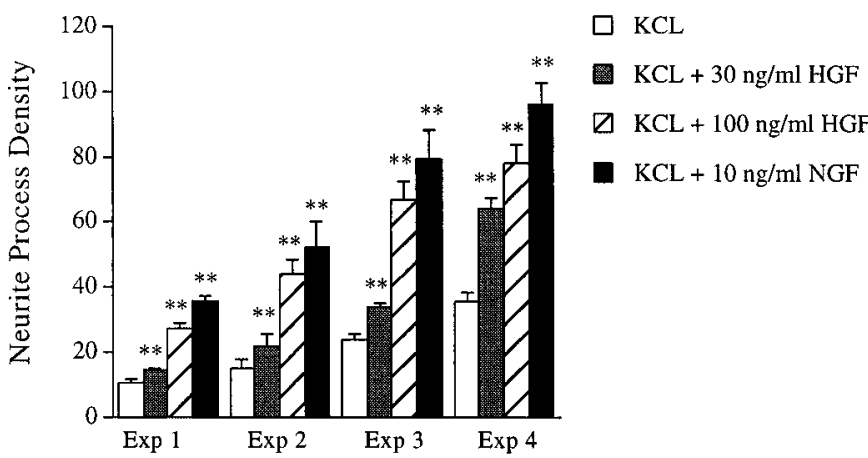

F

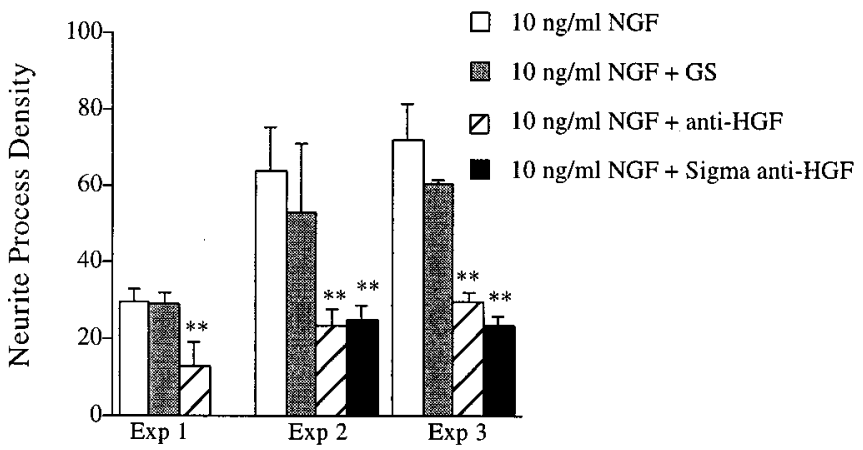

C

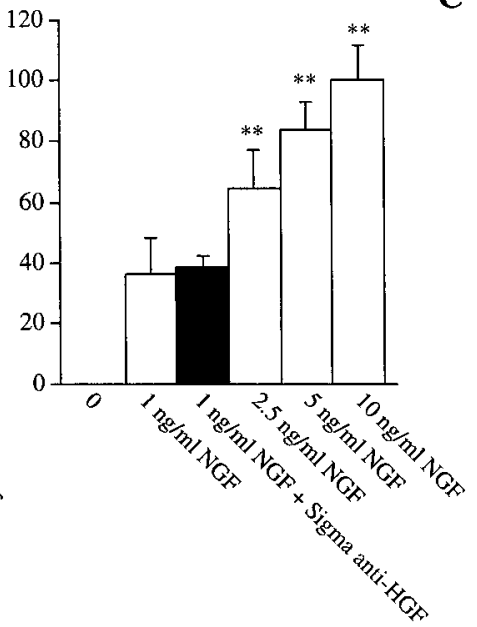

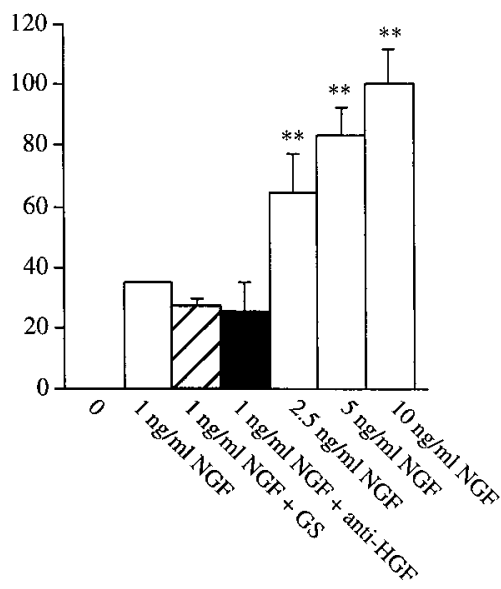

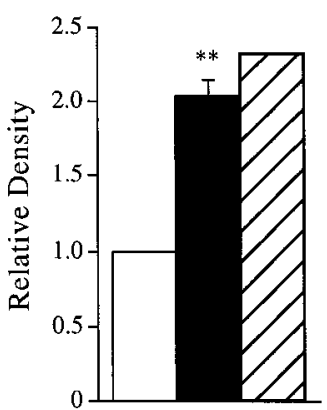

$\square 10 \mathrm{ng} / \mathrm{ml} \mathrm{NGF}$

- $10 \mathrm{ng} / \mathrm{ml} \mathrm{NGF}+\mathrm{HGF}$

】 $40 \mathrm{ng} / \mathrm{ml}$ NGF

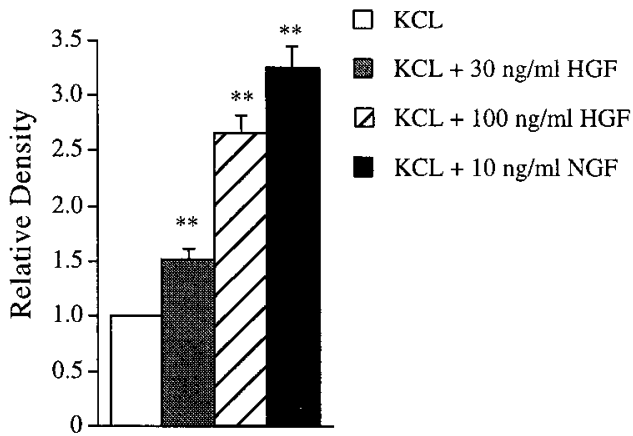

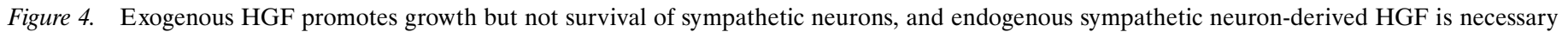

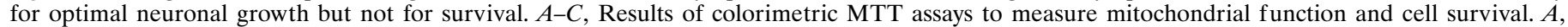

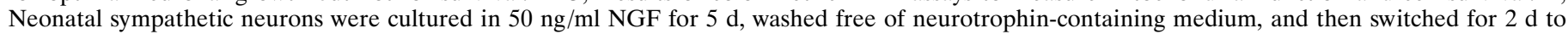

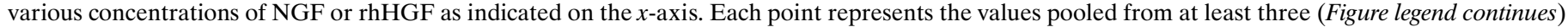


promotes neuronal growth. To determine whether HGF could promote sympathetic neuron growth on its own, we performed similar assays using $\mathrm{KCl}$, an agent that maintains sympathetic neuron survival without promoting growth (Franklin et al., 1995). Specifically, neurons were grown for $4 \mathrm{~d}$ in $10 \mathrm{ng} / \mathrm{ml} \mathrm{NGF}$ and then, after extensive washing, were switched to $50 \mathrm{~mm} \mathrm{KCl}$ with or without 30 or $100 \mathrm{ng} / \mathrm{ml} \mathrm{HGF}$, or $10 \mathrm{ng} / \mathrm{ml} \mathrm{NGF} \mathrm{(Figs.} 4 E$, $5 d-f)$. Two days later, fields were randomly selected, and the process network density was determined. In four separate experiments, the process network density was increased $\sim 1.5 \pm 0.09$ and $2.6 \pm 0.16$ for 30 and $100 \mathrm{ng} / \mathrm{ml} \mathrm{HGF}$, respectively (Figs. $4 E$, Fig. $5 d, e)$. By comparison, addition of $10 \mathrm{ng} / \mathrm{ml}$ NGF increased neurite density by $3.2 \pm 0.19$ (Figs. $4 E, 5 d$, f). Thus, HGF not only enhances sympathetic neuron growth in the presence of NGF, but it can also promote neurite extension on its own.

We next determined whether HGF could promote the rate of forward axonal extension, a second index of sympathetic neuron growth. To measure this parameter, we turned to compartmented cultures of sympathetic neurons, a system (Campenot, 1982a,b, 1992) that allows (1) measurement of the rate of forward axonal growth and (2) independent manipulation of the environment of distal neurites versus that of proximal neurites and cell bodies, thereby allowing for an analysis of local effects on axonal growth. To perform these experiments, we established compartmented cultures with $10 \mathrm{ng} / \mathrm{ml} \mathrm{NGF}$ in the center compartment, $1 \mathrm{ng} / \mathrm{ml}$ NGF in one side compartment, and $1 \mathrm{ng} / \mathrm{ml} \mathrm{NGF}$ plus $30 \mathrm{ng} / \mathrm{ml}$ rhHGF in the other side compartment. The length of axons in the side compartments was then measured every second day for $6 \mathrm{~d}$ (Fig. 6A). This analysis revealed that HGF applied to neurites was capable of modestly enhancing the forward rate of neurite outgrowth over the entire $6 \mathrm{~d}$ period (Fig. $6 A$ ); by the sixth day, there was an increase of $\sim 18 \%$ in the average length of neurites that were exposed to NGF plus HGF versus NGF alone.

In a second set of compartmented culture experiments, we measured the effects of exogenous HGF on the forward rate of axonal extension in the presence of $\mathrm{KCl}$. Specifically, cultures were established with $10 \mathrm{ng} / \mathrm{ml} \mathrm{NGF}$ in all compartments for $4 \mathrm{~d}$ and then were switched to $50 \mathrm{mM} \mathrm{KCl}$ with or without $30 \mathrm{ng} / \mathrm{ml}$ HGF in the side compartments. The extent of forward axonal growth was measured immediately after the switch and then $2 \mathrm{~d}$ later (Fig. 6B). This analysis demonstrated that HGF was capable of promoting forward axonal growth in the absence of NGF, although this effect (Fig. 6B) was not as robust as the effect on neurite density (Fig. $4 E$ ). Together these data indicate that HGF can promote increased neuritic density and forward axonal extension in the presence or absence of NGF. Moreover, our compartmented culture data indicate that HGF can act locally through axonal Met receptors to enhance axonal growth.

\section{Autocrine HGF is essential for optimal morphological growth but not survival of sympathetic neurons}

Together, these data demonstrate that activation of the Met receptor with exogenous $\mathrm{HGF}$ can promote neurite growth independent of an effect on neuronal survival. To determine whether autocrine HGF played a similar role, we inhibited endogenous sympathetic neuron-derived HGF using two different functionblocking HGF antibodies [one commercially available purified anti-HGF IgG from Sigma (Rubin et al., 1991) and one an anti-HGF antiserum that was the kind gift of Genentech (Tsao et al., 1993)]. Initially, we confirmed the previously reported ability of these antibodies to neutralize HGF by determining whether they inhibited the induction of c-fos by exogenous HGF. Specifically, $10 \mathrm{ng} / \mathrm{ml} \mathrm{HGF}$ was preincubated with the anti-HGF at $4^{\circ} \mathrm{C}$ for $3 \mathrm{hr}$ and then was added to acutely dissociated sympathetic neurons; c-fos induction was monitored by immunostaining (Fig. $3 c$ for the Genentech antiserum; data for the Sigma antibody is not shown). As a control, we used $10 \mathrm{ng} / \mathrm{ml} \mathrm{HGF}$ that was not preabsorbed (Fig. 3d). This analysis confirmed that both function-blocking HGF antibodies inhibited the ability of exogenous HGF to induce neuronal c-fos expression.

We then used these antibodies to determine whether endogenous HGF played any role in sympathetic neuron survival or

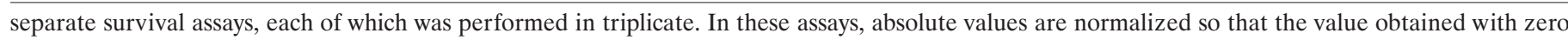

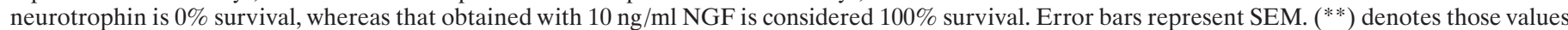

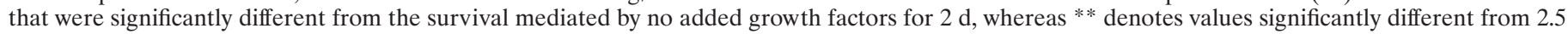

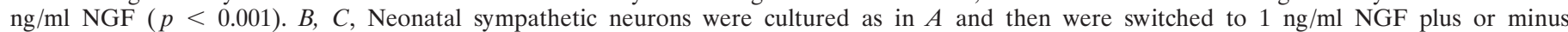

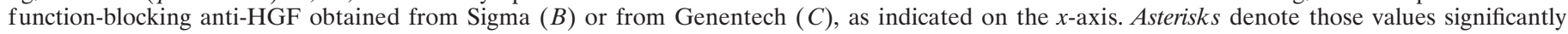

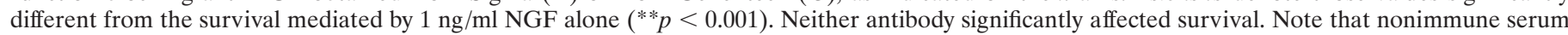

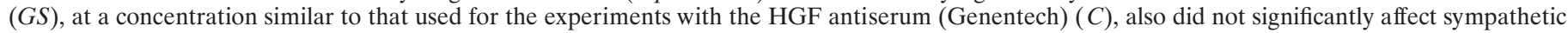

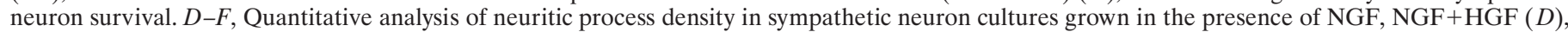

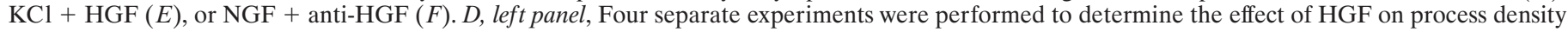

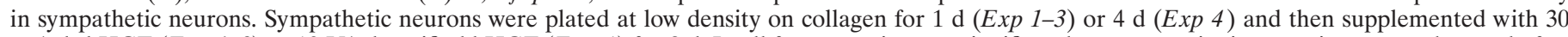

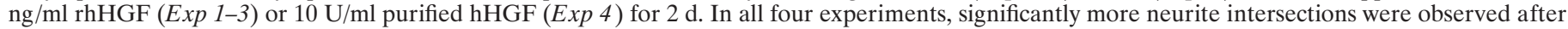

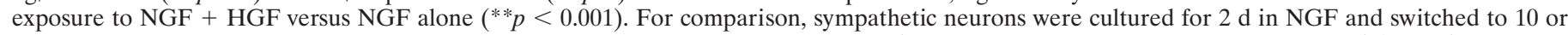

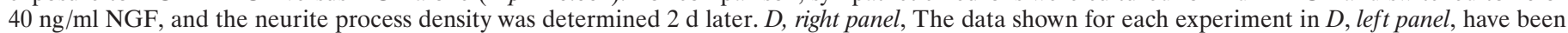

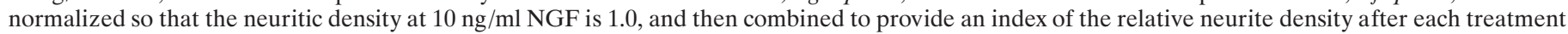

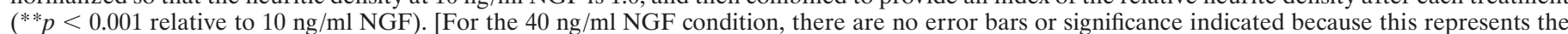

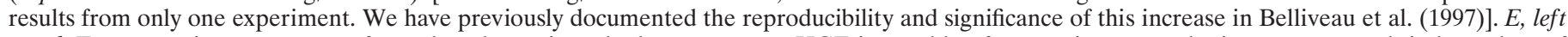

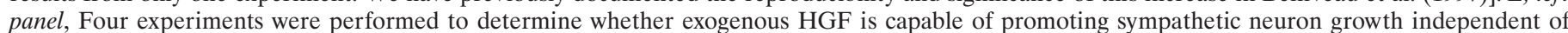

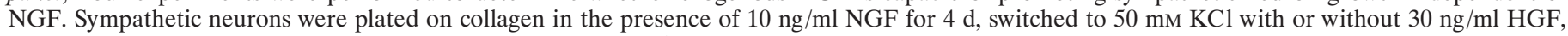

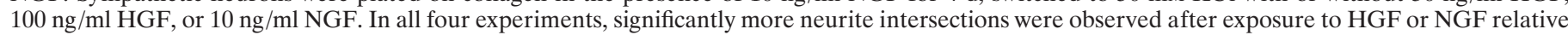

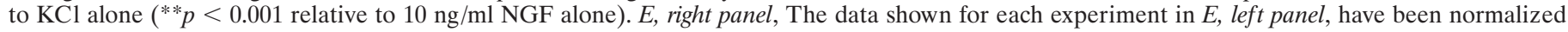

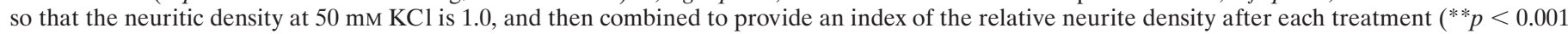

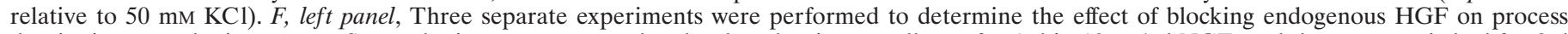

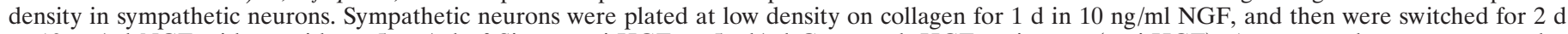

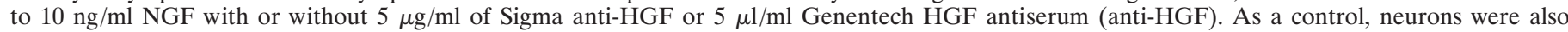

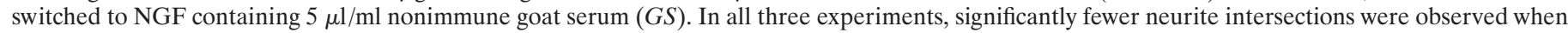

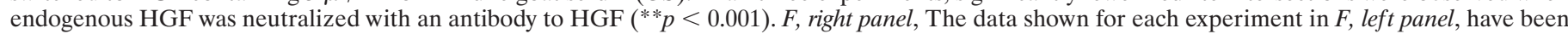

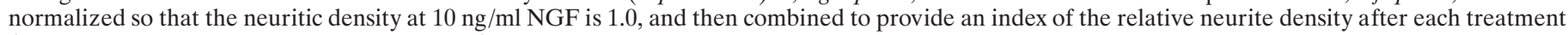
(** $p<0.001$ relative to $10 \mathrm{ng} / \mathrm{ml} \mathrm{NGF}$ alone). 

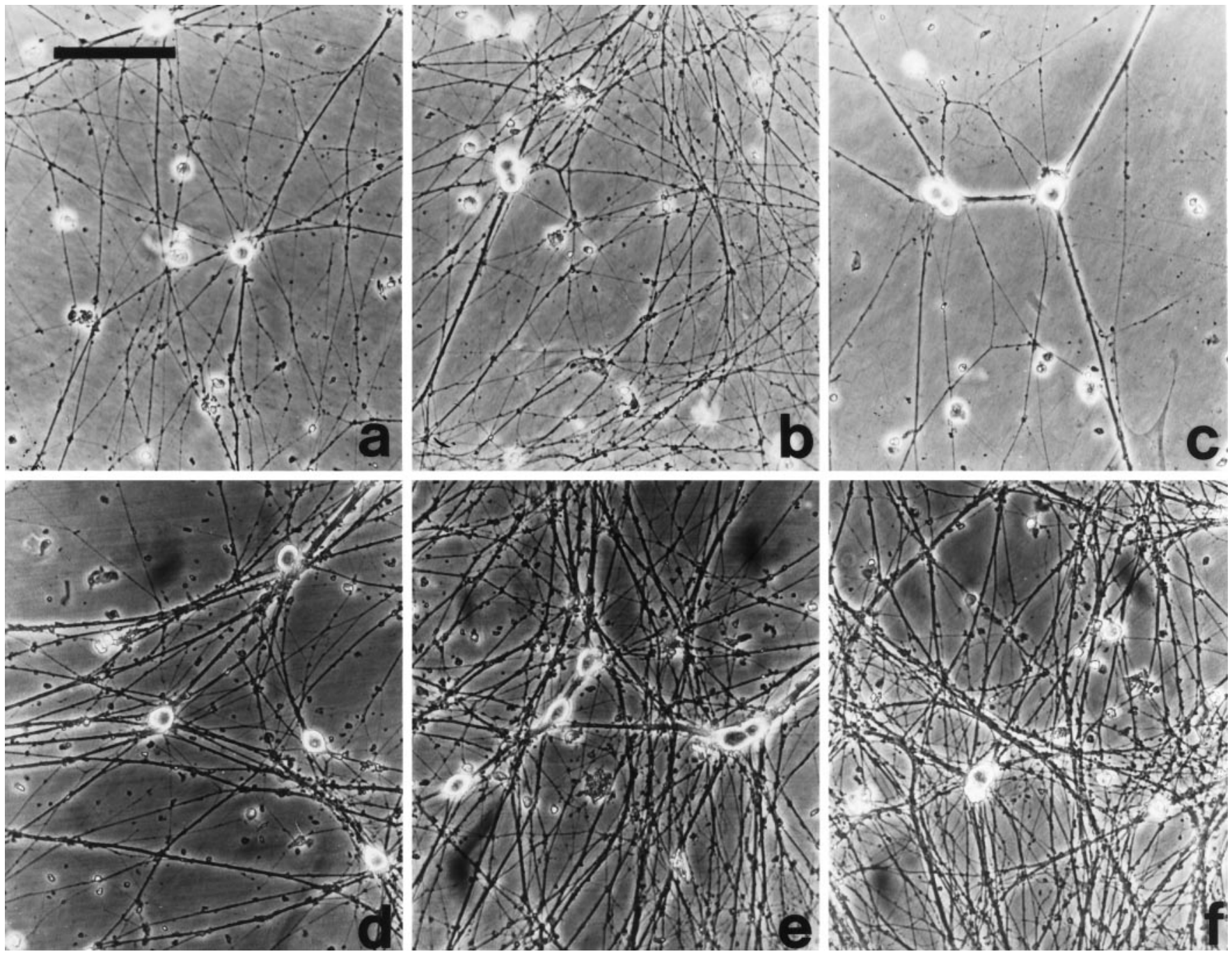

Figure 5. Endogenous HGF is necessary for optimal growth of cultured sympathetic neurons. $a-c$, Phase-contrast micrographs of cultured neonatal sympathetic neurons maintained in $10 \mathrm{ng} / \mathrm{ml}$ NGF for $1 \mathrm{~d}$ and then switched to $(a) 10 \mathrm{ng} / \mathrm{ml} \mathrm{NGF},(b) 10 \mathrm{ng} / \mathrm{ml} \mathrm{NGF} \mathrm{plus} 30 \mathrm{ng} / \mathrm{ml} \mathrm{rhHGF}$, or $(c) 10$ $\mathrm{ng} / \mathrm{ml}$ NGF plus $5 \mu \mathrm{l} / \mathrm{ml}$ HGF antiserum (Genentech). Exogenous HGF enhanced and HGF antibody decreased process outgrowth. $d-f$, Phase-contrast micrographs of cultured neonatal sympathetic neurons maintained in $10 \mathrm{ng} / \mathrm{ml} \mathrm{NGF}$ for $4 \mathrm{~d}$ and then switched to $(d) 50 \mathrm{mM} \mathrm{KCl},(e) 50 \mathrm{~mm} \mathrm{KCl}$ plus $100 \mathrm{ng} / \mathrm{ml} \mathrm{HGF}$, or $(f) 50 \mathrm{~mm} \mathrm{KCl}$ plus $10 \mathrm{ng} / \mathrm{ml} \mathrm{NGF}$. Scale bar (shown in $a$ for $a-f$ ): $100 \mu \mathrm{m}$.

growth. For the survival experiments, sympathetic neurons were cultured for $5 \mathrm{~d}$ in $50 \mathrm{ng} / \mathrm{ml} \mathrm{NGF}$ and then were switched into suboptimal concentrations of NGF with or without anti-HGF (5 $\mu \mathrm{g} / \mathrm{ml}$ for Sigma anti-HGF and $5 \mu \mathrm{l} / \mathrm{ml}$ for Genentech antiHGF). Addition of either the anti-HGF IgG (Sigma) (Fig. 4B) or the anti-HGF antiserum (Genentech) (Fig. $4 C$ ) had no effect on sympathetic neuron survival as mediated by $1 \mathrm{ng} / \mathrm{ml}$ (Fig. $4 B, C$ ) or $5 \mathrm{ng} / \mathrm{ml}$ (data not shown) NGF. Thus, endogenous HGF is apparently not required for NGF-mediated sympathetic neuron survival.

To determine whether endogenous HGF was necessary for neuronal growth, we assayed both neurite density and forward axonal growth rate. To examine effects on density, mass cultures of sympathetic neurons were cultured for $1 \mathrm{~d}$ in defined media containing $10 \mathrm{ng} / \mathrm{ml} \mathrm{NGF}$ and then were switched into NGFcontaining media with or without anti-HGF. Two days later, these cultures were analyzed for neurite process density (Figs. $4 F, 5 a, c$ ). This analysis demonstrated that both of the function-blocking HGF antibodies decreased neurite density by 2.5 - to threefold (Figs. $4 F, 5 c$ ) relative to $10 \mathrm{ng} / \mathrm{ml} \mathrm{NGF}$ alone (Figs. $4 F, 5 a$ ) or relative to $10 \mathrm{ng} / \mathrm{ml}$ NGF plus nonimmune serum (Fig. $4 F$ ). The magnitude of this decrease was similar to that observed in neurons maintained in $50 \mathrm{~mm} \mathrm{KCl}$ alone (which does not support growth) relative to those in $50 \mathrm{~mm} \mathrm{KCl}$ plus $10 \mathrm{ng} / \mathrm{ml} \mathrm{NGF}$ (Fig. $4 E$ ). Thus, the addition of anti-HGF reduced NGF-promoted neurite density to approximately the same degree as switching these neurons from NGF into a survival factor that does not promote growth.

To determine whether autocrine HGF was also necessary for the NGF-promoted rate of forward axonal growth, we performed similar experiments in compartmented cultures. Specifically, compartmented cultures were established with $10 \mathrm{ng} / \mathrm{ml} \mathrm{NGF}$ in the center compartment and one of the side compartments and 10 $\mathrm{ng} / \mathrm{ml}$ NGF plus $5 \mu \mathrm{l} / \mathrm{ml}$ anti-HGF (Genentech) in the other side compartment. The amount of axonal growth was then measured at 3.5, 4.5, and 5.5 d (Fig. 6C, Experiment 1) or at 4, 6, and $7 \mathrm{~d}$ (Fig. 6C, Experiment 2). In both of these experiments, the rate of forward axonal growth was significantly decreased in the compartment containing the HGF antibody relative to axons of the same neurons extending into the control side compartment (Fig. $6 C$ ). At days 5.5 (Experiment 1) and 7 (Experiment 2), the total extension length was decreased an average of 30 and $34 \%$, re- 
spectively, when endogenous HGF was neutralized. As an additional control, we performed experiments in which compartmented cultures were established as above, with one side containing $3 \mathrm{ng} / \mathrm{ml} \mathrm{NGF}$ plus $5 \mu \mathrm{l} / \mathrm{ml}$ nonimmune sheep serum and the other containing $3 \mathrm{ng} / \mathrm{ml} \mathrm{NGF}$ plus $5 \mu \mathrm{l} / \mathrm{ml}$ anti-HGF. In these experiments (Fig. 6D), at $4 \mathrm{~d}$ after addition of anti-HGF, the total extension length was decreased an average of $20 \%$ in the side containing anti-HGF relative to that containing nonimmune serum. Together, these experiments indicate that autocrine HGF is necessary for optimal expression of two different facets of neuronal growth: neuritic density and the forward rate of axonal growth.

\section{Autocrine HGF promotes axonal extension in a local, substrate-independent manner}

The compartmented culture results indicated that axonally produced HGF acted locally to promote an optimal axonal extension rate. However, endogenous HGF could also be promoting sympathetic neuron growth by acting globally, for example, to increase the expression of genes important for neuronal growth (Ma et al., 1992; Belliveau et al., 1997). To test this possibility, we neutralized autocrine HGF in the center compartment of compartmented cultures, which contain neuronal cell bodies and proximal neurites, and determined whether this affected the rate of axonal extension in the side compartments, which contain distal axons. Specifically, compartmented cultures were established with $10 \mathrm{ng} / \mathrm{ml} \mathrm{NGF}$ in all compartments, and then antiHGF (Genentech) was added to the central compartments of half of the sister cultures. The amount of neurite extension was then measured at 4, 5, and $6 \mathrm{~d}$ [three cultures each treatment (Fig. 6E, Experiment 1)] or 4, 6, and $7 \mathrm{~d}$ [three cultures each treatment (Fig. $6 E$, Experiment 2)]. These experiments indicated that the amount of axonal extension was not significantly altered by inhibiting endogenous HGF in the center compartment (Fig. 6E).

One difference between the center and side compartment environments is the presence of serum in the center compartment. To ensure that the lack of effect observed when anti-HGF was added to the center compartment was not caused by this variable, we performed experiments in which serum was added to the side compartments. Specifically, compartments were established with $10 \mathrm{ng} / \mathrm{ml} \mathrm{NGF}$ and $3 \%$ serum in all compartments and $5 \mu \mathrm{l} / \mathrm{ml}$ anti-HGF (Genentech) in one side compartment. The amount of neurite extension was measured at 4, 6, and $7 \mathrm{~d}$ (Fig. 6F). As observed without serum, the amount of forward axonal extension was significantly decreased in the presence of the functionblocking anti-HGF. At 4, 6, and $7 \mathrm{~d}$, the amount of axonal growth was decreased an average of 67,53 , and $48 \%$ in the side compartment containing anti-HGF relative to the control side. Similar results were observed when $5 \mu \mathrm{l} / \mathrm{ml}$ nonspecific sheep serum was added to the side compartment that did not contain anti-HGF (data not shown). To determine whether this phenomena was substrate-dependent, we performed compartmented culture studies on poly-D-lysine/laminin as opposed to collagen. As done previously, compartments were established with $10 \mathrm{ng} / \mathrm{ml}$ NGF in all compartments, $5 \mu \mathrm{l} / \mathrm{ml}$ anti-HGF (Genentech) was added to one side compartment, and the amount of axonal growth was measured at 4, 5, and $6 \mathrm{~d}$ (Fig. 6G). These studies demonstrated that autocrine HGF promoted axonal growth through a substrateindependent mechanism. As observed on collagen, neutralization of local endogenous HGF led to an average decrease in axonal growth of $22 \%$ throughout the entirety of the experiment (Fig. $6 G$, Experiment 1). This inhibition was confirmed in a second experiment in which cultures were measured only at $5 \mathrm{~d}$ (Fig. $6 G$,
Experiment 2; combined data of four cultures); in this case, axonal growth was decreased $18 \%$.

Interestingly, in addition to the decrease in forward rate of growth, there was also a striking decrease in neurite density in the side compartment containing the anti-HGF relative to the control side (Fig. 7a,b). This difference was not obvious on a collagen substratum in compartmented cultures, possibly because the axons fasciculate to a greater degree. To obtain an idea of the total decrease in axonal growth caused by anti-HGF under these conditions, we isolated the total protein from the side compartments of these cultures and measured tubulin levels using Western blots. This analysis (Fig. 7c) revealed a dramatic decrease in the amount of total tubulin in the side compartments treated with anti-HGF versus those without, a decrease that was presumably attributable both to decreased neuritic density and to decreased forward extension. Thus, endogenous local HGF is essential for growth of sympathetic axons, promoting both the rate and density of axonal growth in a substrate-independent manner.

\section{DISCUSSION}

The cellular mechanisms that regulate axonal growth during development or axonal regeneration are not well understood. In this regard, the studies reported here identify a novel mechanism in sympathetic neurons; autocrine HGF provides an intrinsic local motor for promoting axonal growth without affecting neuronal survival. Specifically, our experiments support the following conclusions. First, sympathetic neurons coexpress the Met receptor and HGF, both in vivo and in culture. This Met receptor is functional and is distributed on both neurites and cell bodies, and the HGF is bioactive. Second, exogenous HGF does not support survival of sympathetic neurons but leads to robust neuronal growth, at least partially by locally activating axonal Met receptors. In the presence of low levels of NGF, addition of HGF increases neuritic density to an extent similar to higher levels of NGF. HGF, however, does not require NGF; when neuronal survival is maintained by $\mathrm{KCl}$ [which does not itself promote growth (Franklin et al., 1995)], exogenous HGF robustly increases neurite density and, to a lesser extent, the rate of forward axonal growth. Third, and most important, neutralization of endogenous HGF with function-blocking antibodies does not affect sympathetic neuron survival, but markedly decreases growth. The decrease in neuritic density is comparable to the decrease observed when neurons are switched from $\mathrm{NGF}$ to $\mathrm{KCl}$, whereas there is a lesser but highly significant effect on forward extension rate. Fourth, the effect of HGF on neuronal growth is substrate independent and is at least partially mediated locally; neutralization of axonal HGF decreases the rate and density of axonal growth, whereas neutralization of HGF in cell bodies and proximal neurites does not affect the rate of extension of distal axons. Together, these data support the conclusion that HGF secreted by axons interacts locally with axonal Met receptors to increase the rate and density of axonal growth. This novel local autocrine loop has important implications for neuronal growth both during development and after axonal injury.

What facet of neuronal growth requires autocrine HGF? In these studies, we have demonstrated that neutralization of endogenous HGF affects two different measurements of growth. First, we observed a robust decrease in neurite process density in mass cultures, an alteration that might reflect a decrease in (1) the number of neurites extended per cell, (2) the branching of neurites, and (3) the rate of extension of individual neurites. Second, we observed a smaller but significant decrease in forward axon 
A

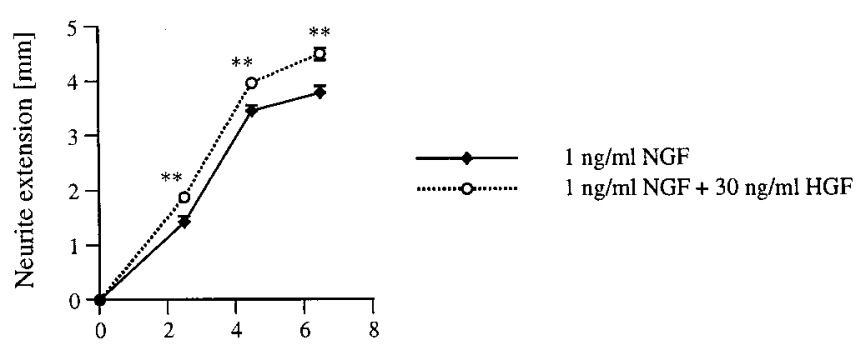

Culture $1-3[\mathrm{~d}=$ days in culture $]$
B

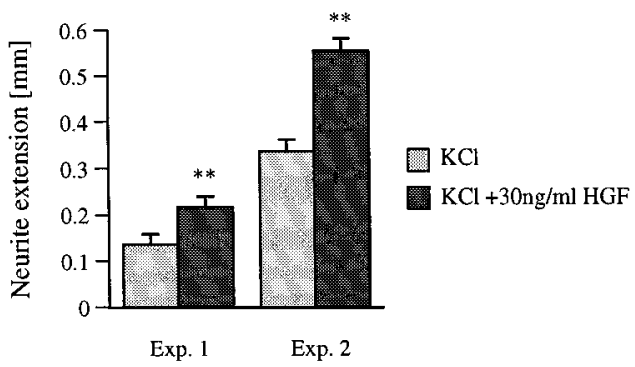

D

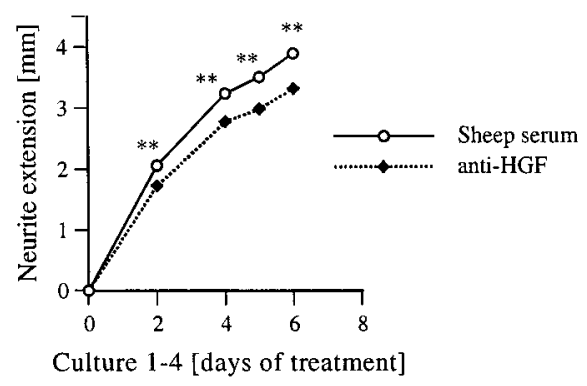

F

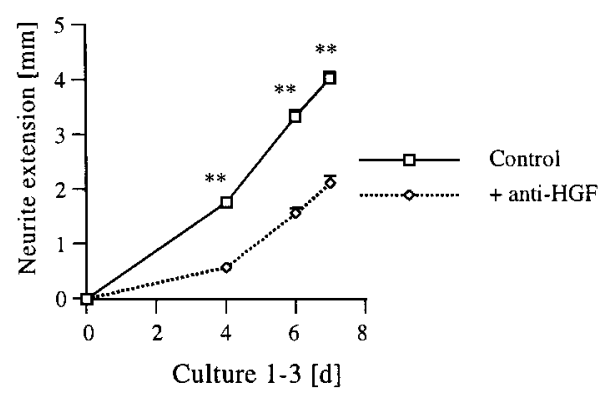

G Experiment 1

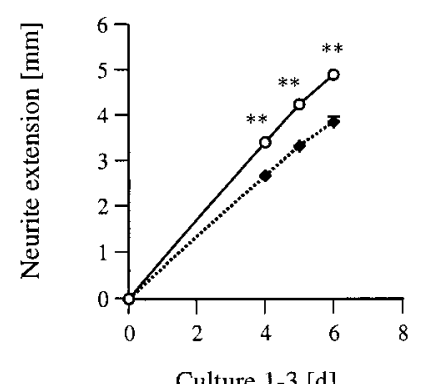

Experiment 2

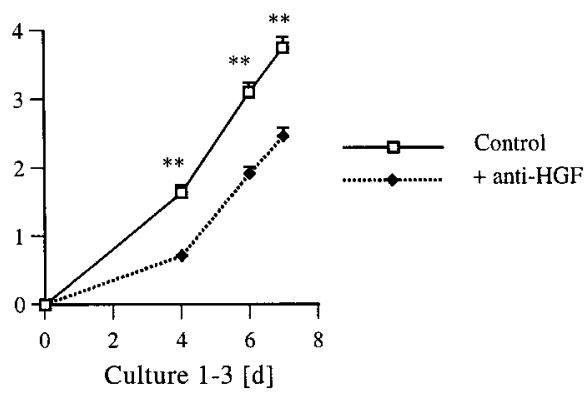

Experiment 2

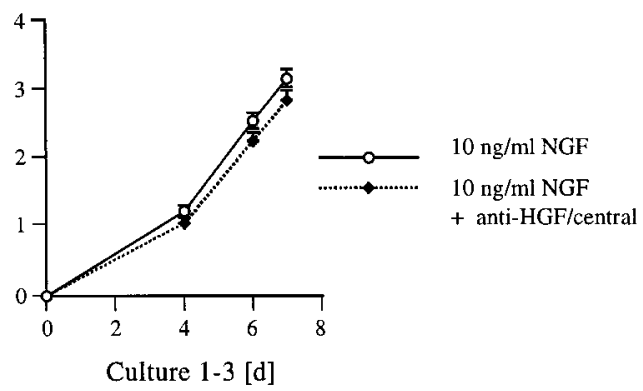

Experiment 2

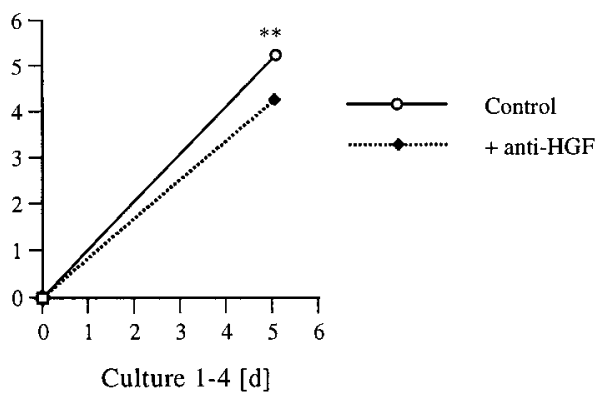

Figure 6. Growth of sympathetic axons in compartmented cultures in the presence of HGF or anti-HGF. $A$, Exogenous HGF promotes the rate of axonal extension by acting locally on axons. Compartmented cultures were established with $10 \mathrm{ng} / \mathrm{ml} \mathrm{NGF}$ in the central compartment, $1 \mathrm{ng} / \mathrm{ml} \mathrm{NGF}$ in one side compartment, and $1 \mathrm{ng} / \mathrm{ml}$ plus $30 \mathrm{ng} / \mathrm{ml} \mathrm{HGF}$ in the other. Plots represent the combined results from three sister cultures showing the average length of neurites at 2.5, 4.5, and $6.5 \mathrm{~d}$ after establishment. Error bars indicate SEM, and asterisks denote those time points where growth was significantly different between the experimental and control sides $(* * p<0.001)$. B. Exogenous HGF promotes the rate of forward axonal growth in the absence of NGF. Compartmented cultures were established in $10 \mathrm{ng} / \mathrm{ml} \mathrm{NGF}$ for $4 \mathrm{~d}$, and then switched to $50 \mathrm{~mm} \mathrm{KCl}$ with or without $30 \mathrm{ng} / \mathrm{ml} \mathrm{HGF}$ in the side compartments. The bar graphs represent the average total length of axon extension (error bars represent SE) over $2 \mathrm{~d}$ in $\mathrm{KCl}$ with or without HGF. A similar HGF-mediated increase was observed in two separate experiments $\left({ }^{* *} p<0.001 ; n=3\right.$ cultures for each treatment in each experiment). $C$, $D$, Endogenous local HGF is necessary for optimal axonal extension rate. C, Compartmented cultures were established (Figure legend continues) 
growth rate. This measure does not itself reflect any alterations in neurite initiation or density and, in fact, remains relatively constant over a broad range of NGF concentrations (data not shown). Thus, although these data indicate that autocrine HGF is required for an optimal axonal extension rate, the greater magnitude of the alterations in neurite density indicate that it is also likely to be essential for either neurite initiation or branching.

Although our data do not directly address the in vivo role of this autocrine growth loop, such an intrinsic motor is likely to be most important during axonal growth before target contact or during neuronal regeneration or both. Sympathetic neurons require nerve growth factor (Levi-Montalcini and Booker, 1960; Crowley et al., 1994) and to a lesser degree NT-3 (El-Shamy et al., 1996; Belliveau et al., 1997) for appropriate target innervation and survival, processes that are regulated via the TrkA and p75 neurotrophin receptors (Lee et al., 1994; Smeyne et al., 1994; Bamji et al., 1998). However, in mice lacking the TrkA receptor, sympathetic neurons undergo initial axogenesis in a manner that is indistinguishable from their wild-type counterparts (Fagan et al., 1996). Developmental deficits occur at a later time point, during the period of target innervation, indicating that sympathetic axogenesis and target innervation are two distinct processes, only the latter of which requires exogenous neurotrophins. Similar "rules" are apparently followed subsequent to injury of mature neurons; axotomized sympathetic axons will regenerate in the absence of NGF, but then require NGF to reinnervate their targets (Gloster and Diamond, 1992, 1995). These studies, together with similar studies of sensory neurons (Diamond et al., 1987, 1992), support the conclusion that target innervation and reinnervation are fundamentally different from axonal growth before target contact and axonal regeneration, with the former requiring target-derived NGF and the latter being intrinsically driven. Our studies provide a mechanism for such intrinsically determined sympathetic axon growth during either development or regeneration: a local autocrine growth factor loop.

Such an HGF autocrine loop is apparently not limited to this later stage of sympathetic neuron development. In particular, a recent report by Maina et al. (1998) indicates that autocrine HGF plays an important role during the differentiation of sympathetic neuroblasts to neurons during their early embryonic development. Exogenous HGF also promotes the growth of these early embryonic sympathetic neurons, at least in part by increasing the number of neurites initiated per neuron. Interestingly, autocrine HGF appears to play no role in regulating sympathetic neuron growth at these early stages, when neurite initiation is occurring in vivo, supporting the idea presented here that autocrine HGF is most important for postmitotic neurons during times when axogenesis is extensive, such as during late embryogenesis and postnatal life and, potentially, during axonal regeneration.

It is as yet unknown whether such an autocrine HGF loop occurs in other neurons. HGF is expressed in neurons throughout the CNS (Jung et al., 1994). Moreover, in the peripheral nervous system, HGF is a survival factor for motor neurons (Wong et al., 1997; Yamamoto et al., 1997), exogenous HGF promotes directed growth of motor axons (Ebens et al., 1997), and the pattern of motor axon growth is abnormal in the Met $-/-$ mice (Ebens et al., 1997). Similar results have been observed for sensory neurons: HGF promotes both their survival and growth, and sensory innervation is perturbed in mice expressing Met receptor mutants (Maina et al., 1997). Although these perturbations are thought to be caused by the loss of paracrine HGF in the environment of the extending axons, it is as yet unknown whether motor or sensory neurons themselves express low levels of HGF at any developmental stage. Moreover, an autocrine axonal HGF loop does not preclude additive effects with any HGF encountered in the path of the growing axons. As shown here, sympathetic axons can still respond to exogenous HGF, even in the presence of an autocrine loop.

How does autocrine activation of the Met receptor promote local axonal growth? Insight into potential mechanisms derives from studies on the metastasis of tumor cells (for review, see Jeffers et al., 1996). In transformed cells, the presence of an autocrine $\mathrm{HGF} / \mathrm{Met}$ receptor loop leads not only to increased mitogenesis but also to increased cellular invasiveness and metastatic potential. This increased metastasis has been attributed to (1) enhancement of the production and secretion of proteases such as collagenase (Rong et al., 1994) and urokinase (Pepper et al., 1992; Jeffers et al., 1996) that degrade the extracellular matrix and (2) direct regulation of cytoskeletal dynamics via substrates of Met such as focal adhesion kinase p125FAK (Matsumoto et al., 1995). These same mechanisms have been shown to play a role in the regulation of growth cone motility. Developing axons are known to secrete proteases, and these proteases are known to regulate neurite extension (for review, see Monard, 1988; Pitt-

$\leftarrow$

with $10 \mathrm{ng} / \mathrm{ml} \mathrm{NGF}$ in all compartments, and $5 \mu \mathrm{l} / \mathrm{ml} \mathrm{HGF}$ antiserum in one side compartment. In Experiment 1 , the results from measurements of neurite length in three sister cultures at 3.5, 4.5, and $5.5 \mathrm{~d}$ with (anti-HGF) or without (Control) anti-HGF were combined. In Experiment 2, the results from measurements of neurite length in the side compartments of three sister cultures at 4, 6, and $7 \mathrm{~d}$ were combined. In both experiments, error bars and significance are as in $A$. In some cases, the error bars fall within the symbols. $D$, Compartmented cultures were initially established with $10 \mathrm{ng} / \mathrm{ml}$ NGF in the center compartment and $3 \mathrm{ng} / \mathrm{ml} \mathrm{NGF}$ in both side compartments. At $2 \mathrm{~d}$ after plating, a time point when all neurites had crossed, $3 \mathrm{ng} / \mathrm{ml} \mathrm{NGF}$ plus $5 \mu \mathrm{l} / \mathrm{ml}$ anti-HGF antiserum (Genentech) was added to one side compartment and $3 \mathrm{ng} / \mathrm{ml}$ plus $5 \mu \mathrm{l} / \mathrm{ml}$ nonimmune sheep serum was added to the other, and neurite lengths were measured immediately. Neurite length was again measured on days 2, 4, 5, and 6; at $3 \mathrm{~d}$, media was replaced with new media containing the same concentrations of NGF, anti-HGF, and nonimmune serum. Results represent data combined from six different cultures from two separate experiments. Errors and significance are as in $A$. E. Anti-HGF in the central compartment does not affect the amount of forward axonal growth in the side compartments. Cultures were established with $10 \mathrm{ng} / \mathrm{ml} \mathrm{NGF}$ in all compartments with or without the addition of $5 \mu \mathrm{l} / \mathrm{ml}$ anti-HGF in the central compartment. Plots represent the results obtained in two separate experiments in which sister cultures (three each with and without anti-HGF) were measured at 2, 5, and $6 \mathrm{~d}$ in Experiment 1 and at 4, 6, and $7 \mathrm{~d}$ in Experiment 2. Error bars and significance are as in $A$. The amount of axonal extension was not significantly affected by anti-HGF in either experiment $(p>0.05) . F$, To control for the effects of rat serum, cultures were established with $10 \mathrm{ng} / \mathrm{ml} \mathrm{NGF}$ plus $3 \%$ rat serum in all compartments with $5 \mu \mathrm{l} / \mathrm{ml}$ anti-HGF in one side compartment. The plot represents the combined data from measurements of neurite length in the compartments with and without anti-HGF in three sister cultures at 4, 6, and 7 d. Error bars and significance are as in $A$. Note that this experiment was performed on sister cultures to those shown in $C$, Experiment 2, demonstrating that anti-HGF had similar effects whether the side compartments contained serum $(F)$ or not $(C$, Experiment 2). $G$, To determine whether the anti-HGF effect was dependent on the substrate, cultures were established on a poly-D lysine/laminin substratum with $10 \mathrm{ng} / \mathrm{ml} \mathrm{NGF} \mathrm{in} \mathrm{all} \mathrm{compartments} \mathrm{and} 5 \mu \mathrm{l} / \mathrm{ml}$ anti-HGF in one side compartment. In Experiment 1, the plot represents the combined measurements of neurite length from three sister cultures at 4, 5, and $6 \mathrm{~d}$ in side compartments with or without anti-HGF. In Experiment 2, the plot represents the combined data from four sister cultures that were measured at $5 \mathrm{~d}$. Error bars and significance are as in $A$. 

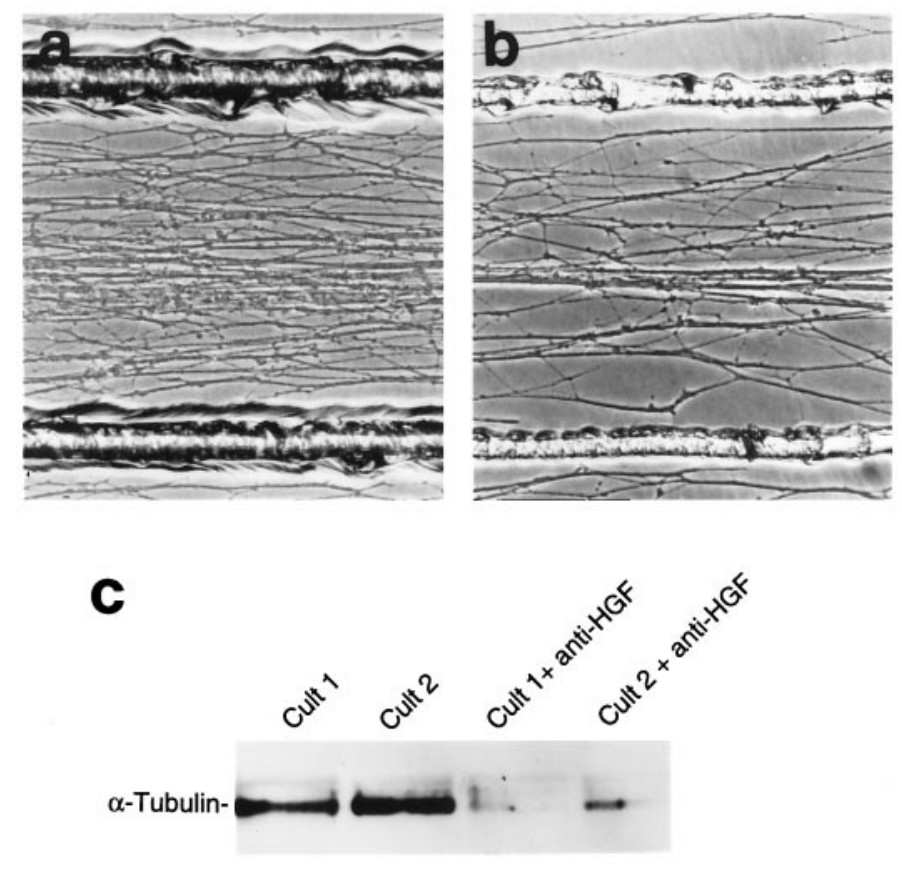

Figure 7. Endogenous HGF is necessary for optimal growth of cultured sympathetic neurons in compartmented cultures. $a, b$, Phase-contrast photomicrographs of neurites on a single track from a sympathetic neuron compartmented culture on poly-D-lysine/laminin where the left compartment $(a)$ has been maintained in $10 \mathrm{ng} / \mathrm{ml} \mathrm{NGF}$, and the right compartment (b) has been maintained in $10 \mathrm{ng} / \mathrm{ml} \mathrm{NGF}$ plus $5 \mu \mathrm{l} / \mathrm{ml} \mathrm{HGF}$ antiserum (Genentech). The photographs were taken $\sim 4 \mathrm{~mm}$ away from the silicone grease barrier that separates the central and side compartments. The scratches in the substratum that form the borders of the track are visible along the top and bottom portion of each panel. Note that the density of neurites in the side compartment containing anti-HGF is significantly lower. $c$, Western blot analysis of $\alpha$-tubulin in lysates of axons in side compartments of compartmented cultures. Side compartments from two of the cultures measured in Figure $6 G$, Experiment 2, were collected on day 6 , lysed, and analyzed for total tubulin per side compartment. Cult 1 refers to one culture and Cult 2 refers to the other. One side compartment (Cult 1 or Cult 2) was treated with $10 \mathrm{ng} / \mathrm{ml}$ NGF alone for $6 \mathrm{~d}$, whereas the other $($ Cult $1+$ anti-HGF, Cult $2+$ anti-HGF) was treated with $10 \mathrm{ng} / \mathrm{ml} \mathrm{NGF}$ plus anti-HGF. The tubulin band is denoted as $\alpha$-Tubulin.

man, 1990). Moreover, growth factors such as the neurotrophins rapidly modify cytoskeletal and growth cone behavior (for review, see Berninger and Poo, 1996). Thus, the same cellular mechanisms that allow an autocrine $\mathrm{HGF} / \mathrm{Met}$ loop to promote invasion and metastasis of tumor cells may well promote the motility and growth of developing sympathetic axons.

Insights into the potential Met-derived signaling pathways that are responsible for mediating this growth response also derive largely from studies on non-neural cells. A number of studies indicate that HGF-induced motility and scatter of MDCK cells requires intact PI3-kinase (Royal and Park, 1995) and Grb2/Ras (Hartmann et al., 1994; Ridley et al., 1995) signaling pathways. Of these two pathways, PI3-kinase may be the more important for Met-mediated neuronal growth, because sensory innervation of transgenic mice is not perturbed by deletion of the Met receptor Grb2 binding site (Maina et al., 1997). Interestingly, TrkA also activates both the Ras and PI3-kinase pathways (for review, see Kaplan and Miller, 1997), and both have been implicated in NGF-induced neurite extension in PC12 cells (Szebereyni et al., 1990; Kimura et al., 1994; Jackson et al., 1996). Thus, these two ligand-receptor systems may use similar signaling pathways to promote neuritic growth, activation occurring in one case in response to autocrine and, potentially, paracrine ligand, and in the other in response to target-derived ligand. Such a model would provide a mechanism for convergence between Met- and TrkA-promoted growth.

In summary, these studies document a novel local mechanism necessary for optimal axonal growth that involves HGF. The autocrine nature of this local motor makes it uniquely suited to drive axonal growth during periods when extrinsic sources of growth factors are few, such as during developmental axon extension and after axonal injury.

\section{REFERENCES}

Acheson A, Conover JC, Fandl JP, DeChiara TM, Russell M, Thadani A, Squinto SP, Yancopoulos GD, Lindsay RM (1995) A BDNF autocrine loop in adult sensory neurons prevents cell death. Nature 374:450-453

Bamji SX, Majdan M, Pozniak CD, Belliveau DJ, Aloyz R, Kohn J, Causing CG, Miller FD (1998) The p75 neurotrophin receptor mediates neuronal apoptosis and is essential for naturally occurring sympathetic neuron death. J Cell Biol 140:911-923.

Belliveau DJ, Krivko I, Kohn J, Lachance C, Pozniak C, Rusakov D, Kaplan D, Miller FD (1997) NGF and neurotrophin-3 both activate TrkA on sympathetic neurons but differentially regulate survival and neuritogenesis. J Cell Biol 136:375-388.

Berninger B, Poo MM (1996) Fast actions of neurotrophic factors. Curr Opin Neurobiol 6:324-330.

Bladt F, Riethmacher D, Isenmann S, Aguzzi A, Birchmeier C (1995) Essential role for the c-met receptor in the migration of myogenic precursor cells into the limb bud. Nature 375:768-771.

Bottaro DP, Rubin JS, Faletto DL, Chan AM-L, Kmiecik TE, Vande Woude GF, Aaronson SA (1991) Identification of the HGF receptor as the c-Met protooncogene product. Science 251:802-804.

Campenot RB (1982a) Development of sympathetic neurons in compartmentalized cultures: I. Local control of neurite growth by nerve growth factor. Dev Biol 93:1-12.

Campenot RB (1982b) Development of sympathetic neurons in compartmentalized cultures: II. Local control of neurite survival by nerve growth factor. Dev Biol 3:13-21.

Campenot RB (1992) Compartmented culture analysis of nerve growth. In: Cell-cell interactions: a practical approach (Stevenson B, Paul D, Gallin W, eds), pp 275-298. Oxford: Oxford UP.

Causing CG, Gloster A, Aloyz R, Bamji SX, Chang E, Fawcett J, Kuchel G, Miller FD (1997) Synaptic innervation density is regulated by neuron-derived BDNF. Neuron 18:257-267.

Chomczynski P, Sacchi N (1987) Single-step method of RNA isolation by acid guanidium thiocyanate-phenol-chloroform extraction. Anal Biochem 62:156-159.

Crowley C, Spencer SD, Nishimura MC, Chen KS, Pitts-Meek S, Armanini MP, Ling LH, McMahon SB, Shelton DL, Levinson AD, Phillips HS (1994) Mice lacking nerve growth factor display perinatal loss of sensory and sympathetic neurons yet develop basal forebrain cholinergic neurons. Cell 76:1-20.

Davies AM (1996) Paracrine and autocrine actions of neurotrophic factors. Neurochem Res 21:749-753.

Diamond J, Coughlin M, MacIntyre L, Homes M, Visheau B (1987) Evidence that endogenous $\beta$ nerve growth factor is responsible for the collateral sprouting, but not the regeneration, of nociceptive axons in the adult rat. Proc Natl Acad Sci USA 84:6596-6600.

Diamond J, Holmes M, Coughlin M (1992) Endogenous NGF and nerve impulses regulate the collateral sprouting of sensory axons in the skin of the adult rat. J Neurosci 12:1454-1466.

Ebens A, Brose K, Leonardo ED, Hanson Jr MG, Bladt F, Birchmeier C, Barres BA, Tessier-Lavigne M (1997) Hepatocyte growth factor/scatter factor is an axonal chemoattractant and a neurotrophic factor for spinal motor neurons. Neuron 17:1157-1172.

Edwards RM, Rutter WJ, Hanahan D (1989) Directed expression of NGF to pancreatic $\beta$ cells in transgenic mice leads to selective hyperinnervation of the islets. Cell 58:161-170.

El-Shamy WM, Linnarsoon S, Lee K-F, Jaenisch R, Ernfors P (1996) Prenatal and postnatal requirements of NT-3 for sympathetic neuroblast survival and innervation of specific targets. Development 122:491-500.

Fabregat I, De Juan C, Nakamura T, Benito M (1992) Growth stimulation of rat fetal hepatocytes in response to hepatocyte growth factor: 
modulation of c-myc and c-fos expression. Biochem Biophys Res Commun 189:684-690.

Fagan AM, Zhang H, Landis S, Smeyne RJ, Silos-Santiago I, Barbacid M (1996) TrkA, but not TrkC, receptors are essential for survival of sympathetic neurons in vivo. J Neurosci 16:6208-6218.

Franklin JL, Sans-rodriguez C, Juhasz A, Deckwerth TL, Johnson Jr EM (1995) Chronic depolarization prevents programmed death of sympathetic neurons in vitro but does not support growth: requirement for $\mathrm{Ca}^{2+}$ influx but not trk activation. J Neurosci 15:643-664.

Gloster A, Diamond J (1992) Sympathetic nerves in adult rats regenerate normally and restore pilomotor function during an anti-NGF treatment that prevents their collateral sprouting. J Comp Neurol 326:363-374.

Gloster A, Diamond J (1995) NGF-dependent and NGF-independent recovery of functional pilomotor activity after chemical sympathectomy with 6-hydroxydopamine. J Comp Neurol 359:586-594.

Hartmann G, Weidner KM, Schwartz H, Birchmeier W (1994) The motility signal of scatter factor-hepatocyte growth factor mediated through the receptor tyrosine kinase Met requires intracellular action of Ras. J Biol Chem 269:21936-21939.

Jackson TR, Blades IJ, Hammonds-Ode LP, Burga CR, Cooke F, Hawkins PT, Wolf AG, Heldman KA, Theibert AB (1996) Initiation and maintenance of NGF-stimulated neurite outgrowth requires activation of phosphoinositide-3-kinase. J Cell Sci 108:289-300.

Jeffers M, Rong S, Vande Woude GF (1996) Hepatocyte growth factor/ scatter factor-Met signaling in tumorigenicity and invasion/metastasis. J Mol Med 74:505-513.

Jung W, Castren E, Odenthal M, Vande Woude GF, Ishii T, Dienes HP, Lindholm D, Schirmacher P (1994) Expression and functional interaction of hepatocyte growth factor-scatter factor and its receptor c-Met in mammalian brain. J Cell Biol 126:485-494.

Kaplan DR, Miller FD (1997) Signal transduction by the neurotrophin receptors. Curr Opin Cell Biol 9:213-221.

Kimura K, Hattori S, Kabuyama Y, Shizawa Y, Takayanagi J, Nakamura S, Toki S, Matsuda Y, Onodera K, Fukui Y (1994) Neurite outgrowth of PC12 cells is suppressed by wortmannin, a specific inhibitor of phosphatidylinositol 3-kinase. J Biol Chem 269:18961-18967.

Lee K-F, Bachman K, Landis S, Jaenisch R (1994) Dependence on p75 for innervation of some sympathetic targets. Science 263:1447-1449.

Levi-Montalcini R, Booker B (1960) Destruction of the sympathetic ganglia in mammals by an antiserum to a nerve-growth protein. Proc Natl Acad Sci USA 46:384-391.

Lindholm D, Carroll P, Tzimagiogis G, Thoenen H (1996) Autocrineparacrine regulation of hippocampal neuron survival by IGF-1 and the neurotrophins BDNF, NT-3 and NT-4. Eur J Neurosci 8:1452-1460.

Ma Y, Campenot RB, Miller FD (1992) Concentration-dependent regulation of neuronal gene expression by nerve growth factor. J Cell Biol 117:135-141.

Maina F, Hilton MC, Ponzetto C, Davies AM, Klein R (1997) Met receptor signaling is required for sensory nerve development and HGF promotes axonal growth and survival of sensory neurons. Genes Dev 11:3341-3350.

Maina F, Hilton MC, Andres R, Wyatt S, Klein R, Davies AM (1998) Multiple roles for hepatocyte growth factor in sympathetic neuron development. Neuron 20:835-846.

Matsumoto K, Kagoshima M, Nakamura T (1995) Hepatocyte growth factor as a potent survival factor for rat pheochromocytoma PC12 cells. Exp Cell Res 220:71-78.

Miller FD, Speelman A, Mathew TC, Fabian J, Chang E, Pozniak C, Toma JG (1994) Nerve growth factor derived from terminals selectively increases the ratio of p75 to trkA NGF receptors on mature sympathetic neurons. Dev Biol 61:206-117.

Monard D (1988) Cell-derived proteases and protease inhibitors as regulators of neurite outgrowth. Trends Neurosci 11:541-544.

Naldini L, Weidner KM, Vigna E, Gaudino G, Bardelli A, Ponzetto C, Narsimhan RP, Hartmann G, Zarnegar R, Michalopoulos GA, Birchmeier W, Comoglio PM (1991) Scatter factor and hepatocyte growth factor are indistinguishable ligands for the Met receptor. EMBO J 10:2867-2878.

Pepper MS, Matsumoto K, Nakamura T, Orci L, Montesano R (1992) Hepatocyte growth factor increases urokinase-type plasminogen activator (u-PA) and u-PA receptor expression in Madin-Darby canine kidney epithelial cells. J Biol Chem 167:20493-20496.

Pittman RN (1990) Developmental roles of proteases and inhibitors. Dev Biol 1:65-74.
Purves D, Snider WD, Voyvodic JT (1988) Trophic regulation of nerve cell morphology and innervation in the autonomic nervous system. Nature 336:123-128.

Ramon y Cajal S (1928) Degeneration of the peripheral stump. In: Degeneration and regeneration of the nervous system, Vol 1 (May RM, ed), pp 100-126. Oxford: Oxford UP.

Richardson PM, McGuinness UM, Aguayo AJ (1980) Axons from CNS neurones regenerate into PNS grafts. Nature 284:264-265.

Ridley AJ, Comoglio PM, Hall A (1995) Regulation of scatter factor/ hepatocyte growth factor responses by Ras, Rac, and Rho in MDCK cells. Mol Cell Biol 15:1110-1122.

Rong S, Oskarsson M, Faletto DL, Tsarfaty T, Resau J, Nakamura T, Rosen E, Hopkins R, Vande Woude GF (1993) Tumorigenesis induced by co-expression of human hepatocyte growth factor and the human met protooncogene leads to high levels of expression of the ligand and receptor. Cell Growth Differ 4:563-569.

Rong S, Segal S, Anver M, Resau JH, Vande Woude GF (1994) Invasiveness and metastasis of NIH 3T3 cells induced by Met-hepatocyte growth factor/scatter factor autocrine stimulation. Proc Natl Acad Sci USA 91:4731-4735.

Royal I, Park M (1995) Hepatocyte growth factor-induced scatter of Madin-Darby canine kidney cells requires phosphatidylinositol 3-kinase. J Biol Chem 270:27780-27787.

Rubin JS, Chan AM-L, Bottaro D, Burgess W, Taylor WJ, Cech AC, Hirschfield DW, Wong J, Miki T, Finch P, Aaronson SA (1991) A broad-spectrum human lung fibroblast-derived mitogen is a variant of hepatocyte growth factor. Proc Natl Acad Sci USA 88:415-419.

Schmidt C, Bladt F, Goedecke S, Brinkmann V, Zschiesche W, Sharpe M, Gherardi E, Birchmeier C (1995) Scatter factor/hepatocyte growth factor is essential for liver development. Nature 373:699-702.

Smeyne RJ, Klein R, Schnapp A, Long LK, Bryant S, Lewin A, Lira S, Barbacid M (1994) Severe sensory and sympathetic neuropathies in mice carrying a disrupted Trk/NGF receptor gene. Nature 368:246-249.

Sonnenberg E, Meyer D, Weidner KM, Birchmeier C (1993) Scatter factor/hepatocyte growth factor and its receptor, the c-Met tyrosine kinase, can mediate a signal exchange between mesenchyme and epithelia during mouse development. J Cell Biol 123:223-235.

Stoker M, Gherardi E, Gray J (1987) Scatter factor is a fibroblastderived modulator of epithelial cell mobility. Nature 327:239-242.

Szebereyni J, Cai H, Cooper GM (1990) Effect of dominant inhibitory Ha-Ras mutation on neuronal differentiation of PC12 cells. Mol Cell Biol 10:5324-5332.

Toma JG, Rogers D, Senger DL, Campenot RB, Miller FD (1997) Spatial regulation of neuronal gene expression in response to nerve growth factor. Dev Biol 184:1-9.

Tsao M-S, Zhu H, Giaid A, Vialle J, Nakamura T, Park M (1993) Hepatocyte growth factor/scatter factor is an autocrine factor for human normal bronchial epithelial and lung carcinoma cells. Cell Growth Differ 4:571-579.

Uehara Y, Minowa O, Mori C, Shiota K, Kuno J, Noda T, Kitamura N (1995) Placental defect and embryonic lethality in mice lacking hepatocyte growth factor/scatter factor. Nature 373:702-705.

Wong V, Glass DJ, Arriaga R, Yancopoulos GD, Lindsay RM, Conn G (1997) Hepatocyte growth factor promotes motor neuron survival and synergizes with ciliary neurotrophic factor. J Biol Chem 272:5187-5191.

Wyatt S, Davies AM (1995) Regulation of nerve growth factor receptor gene expression in sympathetic neurons during development. J Cell Biol 130:1435-1446.

Yamamoto Y, Livet J, Pollock RA, Garces A, Arce V, de Lapeyriere O, Henderson CE (1997) Hepatocyte growth factor (HGF/SF) is a muscle-derived survival factor for a subpopulation of embryonic motoneurons. Development 124:2903-2913.

Yang X-M, Park M (1993) Expression of the Met/hepatocyte growth factor/scatter factor receptor and its ligand during differentiation of murine P19 embryonal carcinoma cells. Dev Biol 157:308-320.

Yang X-M, Vogan K, Gros P, Park M (1996) Expression of the Met receptor tyrosine kinase in muscle progenitor cells in somites and limbs is absent in Splotch mice. Development 122:2163-2171.

Zhu H, Naujokas MA, Park M (1994) Receptor chimeras indicate that the Met tyrosine kinase mediates the motility and morphogenic responses of hepatocyte growth/scatter factor. Cell Growth Differ 5:359-366. 